\title{
Field observations of volatile organic compound (VOC) exchange in red oaks
}

\author{
Luca Cappellin ${ }^{1,2}$, Alberto Algarra Alarcon ${ }^{2,4}$, Irina Herdlinger-Blatt ${ }^{3}$, Juaquin Sanchez ${ }^{1}$, Franco Biasioli ${ }^{2}$, \\ Scot T. Martin ${ }^{1}$, Francesco Loreto ${ }^{5}$, and Karena A. McKinney ${ }^{1}$ \\ ${ }^{1}$ School of Engineering and Applied Sciences, Harvard University, Cambridge, Massachusetts, USA \\ ${ }^{2}$ Research and Innovation Centre, Fondazione Edmund Mach, S. Michele a/A 38010, Italy \\ ${ }^{3}$ Institute of Ion Physics and Applied Physics, University of Innsbruck, Innsbruck 6020, Austria \\ ${ }^{4}$ Institute of Ecology, University of Innsbruck, Innsbruck 6020, Austria \\ ${ }^{5}$ National Research Council, Department of Biology, Agriculture and Food Science (DISBA), Rome 7-00185, Italy \\ Correspondence to: Luca Cappellin (luca.cappellin@fmach.it) and Karena A. McKinney (kamckinney@seas.harvard.edu)
}

Received: 7 October 2016 - Discussion started: 18 October 2016

Revised: 20 January 2017 - Accepted: 2 March 2017 - Published: 29 March 2017

\begin{abstract}
Volatile organic compounds (VOCs) emitted by forests strongly affect the chemical composition of the atmosphere. While the emission of isoprenoids has been largely characterized, forests also exchange many oxygenated VOCs (oVOCs), including methanol, acetone, methyl ethyl ketone (MEK), and acetaldehyde, which are less well understood. We monitored total branch-level exchange of VOCs of a strong isoprene emitter (Quercus rubra L.) in a mixed forest in New England, where canopy-level fluxes of VOCs had been previously measured. We report daily exchange of several oVOCs and investigated unknown sources and sinks, finding several novel insights. In particular, we found that emission of MEK is linked to uptake of methyl vinyl ketone (MVK), a product of isoprene oxidation. The link was confirmed by corollary experiments proving in vivo detoxification of MVK, which is harmful to plants. Comparison of MEK, MVK, and isoprene fluxes provided an indirect indication of within-plant isoprene oxidation. Furthermore, besides confirming bidirectional exchange of acetaldehyde, we also report for the first time direct evidence of benzaldehyde bidirectional exchange in forest plants. Net emission or deposition of benzaldehyde was found in different periods of measurements, indicating an unknown foliar sink that may influence atmospheric concentrations. Other VOCs, including methanol, acetone, and monoterpenes, showed clear daily emission trends but no deposition. Measured VOC emission and deposition rates were generally consistent with their ecosystem-scale flux measurements at a nearby site.
\end{abstract}

\section{Introduction}

Global budgets indicate that biogenic emissions of volatile organic compounds (VOCs) are about an order of magnitude larger than those from anthropogenic sources (Benkovitz et al., 2004; Guenther et al., 1995). VOCs emitted from forest environments account for approximately half of the reactive carbon introduced globally into the atmosphere (Guenther, 2002), with isoprene alone contributing about a third of the worldwide VOC emissions (Guenther et al., 2006). Biogenic VOCs are typically more reactive than anthropogenic ones and more readily contribute to the formation of secondary organic aerosols (Atkinson and Arey, 1998; Carlton et al., 2009; Claeys et al., 2004; Griffin et al., 1999; Helmig et al., 2006; Kanakidou et al., 2005; Kavouras et al., 1998). Oxygenated VOCs (oVOCs) constitute an abundant class of atmospheric VOCs. oVOCs can be emitted from biogenic and anthropogenic sources and are often produced by secondary reactions (mainly VOC oxidation) in the atmosphere (Galbally and Kirstine, 2002; Jacob et al., 2002). The most abundant biogenic oVOC in the troposphere is methanol, typically followed by acetone, formaldehyde, and acetaldehyde. A vast number of other oVOCs are also present in the atmosphere (Goldstein and Galbally, 2007). In particular, oxidation products of isoprene, such as methyl vinyl ketone (MVK), methacrolein (MACR), isoprene hydroperoxides (ISOPOOHs), and isoprene epoxydiols, play a critical role in reactive carbon cycling, SOA formation, and modu- 
lation of the atmospheric oxidation capacity (Rivera-Rios et al., 2014). Atmospheric oVOCs are removed via SOA formation, photooxidation, or dry and wet deposition. Their atmospheric lifetimes vary widely depending on functionality, from several hours for MVK, MACR, and ISOPOOH, to 10 days for methanol and 1 month for acetone.

Forests not only are major sources of biogenic VOCs but also can act as efficient oVOC sinks. oVOCs can be lost by dry deposition onto plant surfaces or by uptake into the plant through the stomata. Recently, plant uptake has been shown to be a more significant mechanism for oVOC removal than previously assumed (Karl et al., 2010). Plant uptake of oVOCs requires an in vivo sink, such as enzymatic consumption (Cojocariu et al., 2004). Despite many studies documenting plant uptake, the mechanisms of these sinks, which vary across compounds, are not yet fully understood. Uptake of methanol and acetaldehyde by plants has been reported (Jardine et al., 2008; Laffineur et al., 2012), and mechanisms for their metabolism within plants have been proposed (Gout, 2000; MacDonald and Kimmerer, 1993). As both biogenic sources and sinks of these compounds exist, bidirectional exchange can be observed (Jardine et al., 2008; Karl et al., 2010; Laffineur et al., 2012; Misztal et al., 2011; Schade et al., 2011). Similarly, there are many reports of negative acetone fluxes at ecosystem level (Karl et al., 2004, 2005), suggesting deposition or plant uptake. However, evidence for acetone uptake at plant level is inconclusive (Cojocariu et al., 2004; Tani and Hewitt, 2009), and no mechanism driving acetone uptake by plants is known (Cojocariu et al., 2004).

A plant sink of isoprene oxidation products MACR and MVK has also been demonstrated (Andreae et al., 2002; Karl et al., 2004, 2005, 2010), suggesting a metabolic consumption of these compounds, especially given that MVK and MACR are toxic. For MACR, detoxification mechanisms have already been elucidated (Muramoto et al., 2015), whereas knowledge of metabolic pathways consuming MVK is scant. At the same time, some studies have suggested that isoprene plays an antioxidant role within plants, reacting with reactive oxygen species (ROS) to produce MVK and MACR, which are then emitted (Fares et al., 2015; Jardine et al., 2012). Production and emission of isoprene oxidation products by plants is still matter of debate, but if it does occur, it could explain why a detoxification mechanism for MVK and MACR also exists. Moreover, very little is known about plant emission and uptake of other common biogenic oVOCs, such as methyl ethyl ketone (MEK). MEK can lead to ozone and PAN production in the atmosphere (Pinho et al., 2005) and photochemical odd-hydrogen formation in the upper troposphere (Atkinson, 2000; Baeza Romero et al., 2005). Recent studies point out the great importance of biogenic MEK sources (Yáñez-Serrano et al., 2016); however, the origin of biogenic MEK remains unclear.

Among observed oVOCs, several belong to the class of benzenoid compounds, which are believed to be synthesized and emitted by vegetation under stress conditions and as chemical signals, although direct observations of such compounds are still very limited (Bouvier-Brown et al., 2009; Heiden et al., 1999; Jardine et al., 2010; Kim et al., 2010; Leone and Seinfeld, 1984; Misztal et al., 2010, 2015; Owen et al., 2002; White et al., 2009). Uptake of benzenoid compounds such as phenol and benzaldehyde has been seen in houseplants but has not been reported in forest environments so far (Kondo et al., 1996; Tani and Hewitt, 2009). In general, the impact of vegetation on the atmospheric concentrations of benzenoid compounds has usually been overlooked. Only recently, the first suggestion emerged that plant emissions of benzenoid compounds might be comparable to those from anthropogenic sources (Misztal et al., 2015).

In general, direct plant-level field observations of the balance between emissions and deposition of oVOCs are scarce. The present study aims to directly investigate exchange of oVOCs at branch level in a forest environment. The compounds include methanol, acetone, acetaldehyde, MEK, the isoprene oxidation products MACR, MVK, and ISOPOOH, and the aromatic compound benzaldehyde. Isoprene and monoterpenes are also included as references. Emissions and/or uptake of each compound compared with the literature reports and with recent canopy-scale flux measurements at a nearby site (McKinney et al., 2011). Moreover, observations were corroborated with ancillary fumigation experiments with oVOC standards. The results (i) advance the current understanding of oVOC exchange, suggesting plant detoxification of MVK and a mechanistic explanation for the emission of MEK; (ii) provide direct evidence of oVOC exchange at branch level, testing in particular the presence of bidirectional exchange of benzenoids; (iii) suggest avenues for further mechanistic studies on oVOC exchange.

\section{Materials and methods}

\subsection{Forest site description}

Experiments were performed at Harvard Forest, a New England mixed forest located in Petersham, MA $\left(42.54^{\circ} \mathrm{N}\right.$, $72.17^{\circ} \mathrm{W}$; elevation $340 \mathrm{~m}$ ), a rural area in central Massachusetts. Measurements were made from a walk-up tower $(30 \mathrm{~m})$ installed in 2013 and surrounded predominantly by red oak trees. The tower is about $350 \mathrm{~m} \mathrm{SW}$ of the Environmental Measurement Site (EMS) where previous VOC measurements were taken at ecosystem level (McKinney et al., 2011; Moody et al., 1998). A survey of the tree species present at EMS is reported in Urbanski et al. (2007): the mixed forest stand encompasses red oak (36\% of biomass), red maple $(22 \%)$, hemlock $(13 \%)$, red pine $(8 \%)$, birch $(5 \%)$, white pine $(6 \%)$, cherry $(3 \%)$, spruce $(2 \%)$, and beech $(0.8 \%)$. The species distribution at the walk-up tower site is similar but not identical. The tower is constructed on slightly hilly terrain surrounded by forest for several kilo- 
meters. The closest paved road is about $1.5 \mathrm{~km}$ and the nearest town is approximately $5 \mathrm{~km}$ distant. Anthropogenic VOCs come from regional-scale transport especially from cities on the east coast (including Boston, New York, and Albany, located approximately $110 \mathrm{~km}$ to the east, $300 \mathrm{~km}$ to the southeast, and $130 \mathrm{~km}$ to the west of the forest, respectively). Midday ozone concentrations during summers are typically $40 \pm 12 \mathrm{ppbv}$ for periods of NW winds and $58 \pm 19 \mathrm{ppbv}$ for periods of $\mathrm{SW}$ winds, while $\mathrm{NO}_{y}$ (i.e., the sum of nitric oxide, nitrogen dioxide, nitric acid, and organic nitrates) is $2.3 \pm 1.4 \mathrm{ppbv}$ and $5.1 \pm 2.7 \mathrm{ppbv}$, respectively (Moody et al., 1998; Munger et al., 1996).

The forest stand is $85-120$ years old and has been mainly undisturbed over the past 70 years (Urbanski et al., 2007). The canopy is about $22.5 \mathrm{~m}$ high. Measurements of forest leaf area index are routinely made as well as meteorological data (Boose, 2001). Branch enclosure measurements were made using canopy-top branches of red oaks located on the south or east side of the tower.

\subsection{Vertical VOC concentration profiles}

Air samples were drawn from several heights on the tower $(7.5,15,22.5,30 \mathrm{~m})$ through FEP Teflon tubing $(0.635 \mathrm{~cm}$ outer diameter $\times 0.396 \mathrm{~cm}$ inner diameter) connected to a Teflon valve system (NResearch, Inc.) located at $22.5 \mathrm{~m}$ on the tower. A $40 \mathrm{~m}$ FEP Teflon $(0.635 \mathrm{~cm}$ OD $\times 0.396 \mathrm{~cm}$ ID) line connected the valve system with a shed located at the bottom of the tower and housing the analytical instrumentation. The air flow rate through the line was set to ca. $11 \mathrm{~L} \mathrm{~min}^{-1}$ to achieve residence times of ca. $7 \mathrm{~s}$. A filter ( $2.0 \mu \mathrm{m}$ pore size $47 \mathrm{~mm}$ diameter Zefluor PTFE filter, Pall Corp.) was placed at each inlet to prevent particles from entering. Filters were replaced weekly. The valve system was set to cycle between the inlets every $10 \mathrm{~min}$ ( $30 \mathrm{~min}$ in the case of tower top inlet) so that all inlets were measured in random order every $60 \mathrm{~min}$. The inlets not sampled during a given measurement cycle were flushed by a second pump. In this way air was flowing continuously though all inlet lines, preventing signal transients upon valve switching. Of the sample flow, $200 \mathrm{sccm}$ was drawn continuously by a proton transfer reaction time-of-flight mass spectrometer (PTR-ToF-MS) equipped with a switchable reagent ion system (PTR/SRI-ToF-MS) for analysis. Measurements were taken between 17 July and 8 August 2014. The instrument was operated in $\mathrm{NO}^{+}$mode during the period 17-23 July and in $\mathrm{H}_{3} \mathrm{O}^{+}$mode otherwise (see Sect. 2.4).

Background measurements were made by adding zero air to the inlet line at tower top through a third FEP Teflon line. Zero air was generated by compressing ambient air and delivering it to a catalytic converter consisting of palladium coated alumina heated to $290^{\circ} \mathrm{C}$ (Aadco Instruments ZA30). Background measurements were taken automatically every $11 \mathrm{~h}$ for $30 \mathrm{~min}$.

\subsection{Branch enclosure VOC exchange measurements}

Red oak branches accessible from the walk-up tower were selected for branch enclosure measurements. Three cylindrically shaped PFA Teflon branch enclosures (ca. 5L) were used to encase three unshaded upper-canopy branches (22.5 $\mathrm{m}$ above ground). At the end of the experiments leaves were collected and leaf areas were measured via the software ImageJ (version 1.47; Schneider et al., 2012). A fourth, empty enclosure was placed close to the others to serve as a background.

Ambient air was continuously supplied to each enclosure via FEP Teflon tubing $(0.635 \mathrm{~cm}$ OD $\times 0.396 \mathrm{~cm}$ ID) at a flow rate of ca. $2.5 \mathrm{~L} \mathrm{~min}^{-1}$ maintained by a pump. Flows were measured by flow meters (Honeywell AWM5000 series) calibrated using Bios DryCal Flow Calibrators (Bios Defender 520-H and 520-L). Branch enclosure air was drawn through FEP Teflon tubing $(0.635 \mathrm{~cm} \mathrm{OD} \times 0.396 \mathrm{~cm}$ ID) to a Teflon valve system located at $22.5 \mathrm{~m}$ on the tower. The valve system previously described for gradient measurements was reconfigured for this purpose. The air flow rate through the sample line was set at $2 \mathrm{~L} \mathrm{~min}^{-1}$ to achieve residence times in the enclosure sample line of $38 \mathrm{~s}$. Outlet flows were set lower than the inlet flows and excess air was allowed to exit the enclosures through a $30 \mathrm{~cm}$ length of FEP Teflon tubing $(0.635 \mathrm{~cm} \mathrm{OD} \times 0.396 \mathrm{~cm}$ ID). In this way a slight overpressure was created in the enclosures, preventing outside air from entering. Each branch enclosure was sampled for $10 \mathrm{~min}$, followed by $10 \mathrm{~min}$ from the empty enclosure. The valve system was set to cycle among the branch enclosures so that all of them were measured in random order. The first 3 min of each measurement were discarded to avoid artifacts from the previous sample. The enclosures not sampled during a given measurement cycle were flushed by a second pump. In this way air was flowing continuously though all enclosures and inlet lines, preventing signal transients upon valve switching.

A PTR/SRI-ToF-MS instrument was continuously drawing $200 \mathrm{sccm}$ of the sample flow for analysis. VOC exchange rates were computed from differences between the concentration in the branch enclosure and those in the empty enclosure, converted in nmol m $\mathrm{m}^{-2} \mathrm{~h}^{-1}$ using the measured leaf area and ingoing flow rate. Measurements were taken between 14 August and 1 September 2014. The present study reports measurements for a particular period and compares them with canopy-level fluxes measured in similar periods but different years. A long-term survey of flux dynamics is beyond the scope of the present paper. The instrument was operated in $\mathrm{NO}^{+}$mode during the periods 14-21 and 28 August-1 September, and in $\mathrm{H}_{3} \mathrm{O}^{+}$mode otherwise (see Sect. 2.4).

On 2 September ancillary fumigation experiments were carried out. Gas cylinders containing known amounts of the target VOCs (Scott Specialty Gases, Inc.) were diluted with zero air using mass flow controllers (MKS Instruments) and 
Table 1. Average measured emission and deposition rates at branch scale in the upper canopy (14-25 August). Data are reported as mean \pm standard deviation. Maximum emission and deposition rates are also reported as well as an indication of their statistical significance ${ }^{*}$ indicates $p<0.05$; n.s. indicates not significant).

\begin{tabular}{|c|c|c|c|c|c|}
\hline & $\begin{array}{l}\text { Average daytime } \\
\text { emission } \\
\left(\mathrm{nmol} \mathrm{m}^{-2} \mathrm{~h}^{-1}\right)\end{array}$ & $\begin{array}{l}\text { Average nighttime } \\
\text { emission } \\
\left(\mathrm{nmol} \mathrm{m}^{-2} \mathrm{~h}^{-1}\right)\end{array}$ & $\begin{array}{l}\text { Average } 24 \mathrm{~h} \\
\text { emission } \\
\left(\mathrm{nmol} \mathrm{m}^{-2} \mathrm{~h}^{-1}\right)\end{array}$ & $\begin{array}{l}\text { Maximum } \\
\text { emission rate } \\
(1 \mathrm{~h} \text { integration }) \\
\left(\mathrm{nmol} \mathrm{m}^{-2} \mathrm{~h}^{-1}\right)\end{array}$ & $\begin{array}{l}\text { Maximum } \\
\text { deposition rate } \\
(1 \mathrm{~h} \text { integration }) \\
\left(\mathrm{nmol} \mathrm{m}^{-2} \mathrm{~h}^{-1}\right)\end{array}$ \\
\hline Benzaldehyde & $0.6 \pm 0.3$ & $0.2 \pm 0.1$ & $0.4 \pm 0.2$ & $2.2^{*}$ & $-1.9^{*}$ \\
\hline Acetaldehyde & $50 \pm 30$ & $11 \pm 6$ & $20 \pm 10$ & $170^{*}$ & $-20 *$ \\
\hline MEK & $30 \pm 10$ & $4 \pm 3$ & $15 \pm 7$ & $140^{*}$ & 0 \\
\hline ISOP & $2 \pm 1 \times 10^{4}$ & $20 \pm 20$ & $1 \pm 0.7 \times 10^{4}$ & $1.0 \times 10^{5^{*}}$ & 0 \\
\hline Monoterpenes & $20 \pm 10$ & $2 \pm 2$ & $10 \pm 7$ & $183^{*}$ & 0 \\
\hline $\mathrm{MACR}+\mathrm{MVK}+\mathrm{ISOPOOH}$ & - & $0 \pm 2$ & - & 7 n.s. & $-4^{*}$ \\
\hline
\end{tabular}

Table 2. Average measured emission and deposition rates at branch scale in the upper canopy (25 August-1 September). Data are reported as mean \pm standard deviation. Maximum emission and deposition rates are also reported as well as an indication of their statistical significance (* indicates $p<0.05 ;$ n.s. indicates not significant).

\begin{tabular}{llllll}
\hline & $\begin{array}{l}\text { Average daytime } \\
\text { emission }\end{array}$ & $\begin{array}{l}\text { Average nighttime } \\
\text { emission }\end{array}$ & $\begin{array}{l}\text { Average } 24 \mathrm{~h} \\
\text { emission }\end{array}$ & $\begin{array}{l}\text { Maximum } \\
\text { emission rate } \\
(1 \mathrm{~h} \text { integration }) \\
\left(\mathrm{nmol} \mathrm{m}^{-2} \mathrm{~h}^{-1}\right)\end{array}$ & $\begin{array}{l}\text { Maximum } \\
\text { deposition rate } \\
(1 \mathrm{~h} \text { integration }) \\
\left(\mathrm{nmol} \mathrm{m}^{-2} \mathrm{~h}^{-1}\right)\end{array}$ \\
\hline Benzaldehyde & $-1 \pm 2$ & $0 \pm 1$ & $-1 \pm 2$ & $0.5^{*}$ & $-7^{*}$ \\
Acetaldehyde & $10 \pm 40$ & $-1 \pm 10$ & $3 \pm 18$ & $100^{*}$ & $-40^{*}$ \\
MEK & $60 \pm 20$ & $7 \pm 7$ & $30 \pm 20$ & $460^{*}$ & 0 \\
Acetone & $50 \pm 20$ & $10 \pm 10$ & $30 \pm 20$ & $340^{*}$ & 0 \\
MeOH & $1000 \pm 1000$ & $300 \pm 200$ & $700 \pm 600$ & $3000^{*}$ & 0 \\
ISOP & $4 \pm 4 \times 10^{4}$ & $20 \pm 10$ & $2 \pm 2 \times 10^{4}$ & $3.2 \times 10^{*}$ & 0 \\
Monoterpenes & $50 \pm 50$ & $20 \pm 10$ & $40 \pm 40$ & $1370^{*}$ & $\left.-50 \mathrm{n}^{-1}\right)$ \\
MACR + MVK+ ISOPOOH & - & $-6 \pm 8$ & - & 0 & $-23^{*}$ \\
\hline
\end{tabular}

delivered to the branch enclosures. Tested VOCs included isoprene $(80 \mathrm{ppm} \pm 5 \%$ in the gas cylinder), MVK $(1 \mathrm{ppm})$, MACR $(1 \mathrm{ppm} \pm 5 \%)$, acetone $(1 \mathrm{ppm} \pm 5 \%)$, and methanol $(1 \mathrm{ppm} \pm 5 \%)$. For each VOC different concentrations in the range $0-70 \mathrm{ppbv}$ (0-700 for isoprene) were delivered to the branch enclosures. Flow rates were set as previously described. For each concentration step, the enclosures, including the empty one, were measured in random order and the signal was allowed to stabilize (typically for tens of minutes) before a measurement was made. The PTR/SRI-ToF-MS was operated in $\mathrm{NO}^{+}$mode. VOC exchange rates were computed as described above. During the ancillary experiments daytime temperature and PAR were in the ranges $27.1-28.2^{\circ} \mathrm{C}$ and $894-1584 \mu \mathrm{mol} \mathrm{m}^{-2} \mathrm{~s}^{-1}$, respectively, while nighttime temperature was in the range $20.7-22.2^{\circ} \mathrm{C}$.

\subsection{PTR/SRI-ToF-MS operation and data analysis}

VOC measurements were performed by a PTR/SRI-ToF-MS 8000 (Ionicon Analytik GmbH, Innsbruck Austria) equipped with a switchable reagent ion system (Jordan et al., 2009), allowing either $\mathrm{NO}^{+}$or $\mathrm{H}_{3} \mathrm{O}^{+}$primary ion chemistry.

Details of the instrument operation are reported in the Supplement.

\section{Results and discussion}

Averaged rates of exchange of the most important oVOCs and volatile isoprenoids measured in the present experiments at Harvard Forest are reported in Tables 1 and 2 and Fig. 1. The reported compounds were selected based on canopyscale flux measurements previously performed at a nearby site (McKinney et al., 2011) with the addition of benzaldehyde. The results differ strongly among compounds, and each compound is discussed separately below. The main focus is investigating factors affecting bidirectional exchange of oVOCs with the forest upper canopy. Vertical concentration profiles and corollary fumigation experiments are used to corroborate conclusions. 


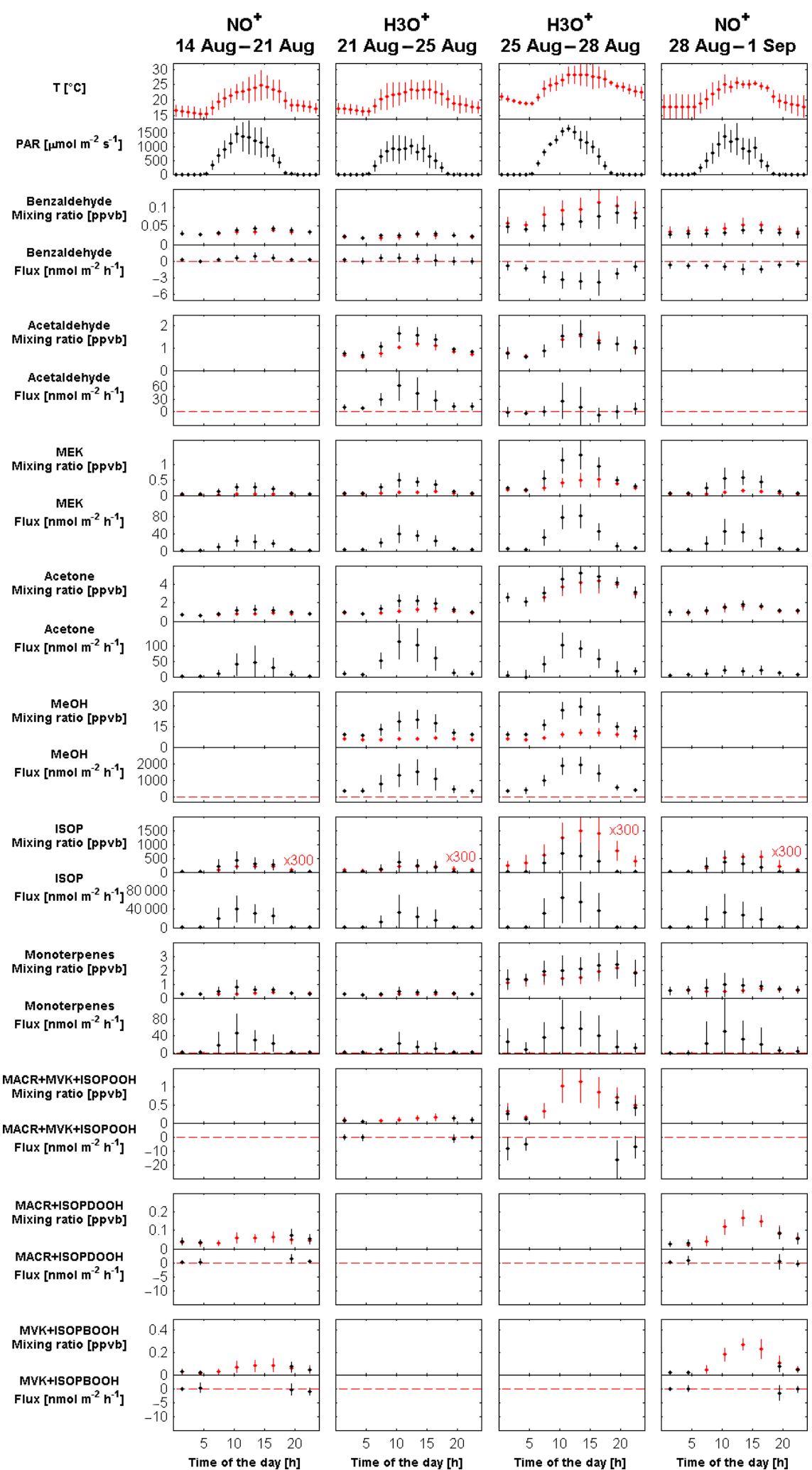

Figure 1. Diel average measured mixing ratios and fluxes in enclosures containing upper-canopy red oak branches at Harvard Forest. Mixing ratios of the inflow ambient air and of the outflow air are shown in red and black, respectively. Diel average temperature and PAR during the measurement period are also shown. Error bars represent standard errors of the data points in each time interval. 


\subsection{Isoprene}

As expected, isoprene emission showed a diel cycle peaking in the middle of the day and dropping at night (Fig. 1). Isoprene emission during daytime averaged to ca. $3 \times$ $10^{4} \mathrm{nmol} \mathrm{m}^{-2} \mathrm{~h}^{-1}$ (ca. $2 \mathrm{mg} \mathrm{m}^{-2} \mathrm{~h}^{-1}$ ) on a leaf area basis, with peaks of $32 \times 10^{4} \mathrm{nmol} \mathrm{m}^{-2} \mathrm{~h}^{-1}\left(22 \mathrm{mg} \mathrm{m}^{-2} \mathrm{~h}^{-1}\right)$. No isoprene uptake was detected. Likewise, ancillary experiments (Table 1) showed no deposition during isoprene fumigation of the same upper-canopy branches. Figure 2 shows daytime and nighttime isoprene concentrations at different heights within and above the canopy. This vertical profile is consistent with an isoprene source within the canopy during the day, while it suggests that there is no isoprene emission nor deposition at night.

Literature findings are in agreement with these results. Sharkey et al. (1996) reported emissions of isoprene of ca. $15 \times 10^{4} \mathrm{nmol} \mathrm{m}^{-2} \mathrm{~h}^{-1}$ (at $30^{\circ} \mathrm{C}$ and PPFD of $1000 \mu \mathrm{mol} \mathrm{m}^{-2} \mathrm{~s}^{-1}$ ) from red oak leaves in a mixed forest. McKinney et al. (2011) reported isoprene canopy fluxes at an adjacent site in the range of ca. $1-8 \mathrm{mg} \mathrm{m}^{-2} \mathrm{~h}^{-1}$ on a ground area basis. This magnitude is also consistent with the current results, which correspond to daytime average isoprene fluxes of ca. $2-3 \mathrm{mg} \mathrm{m}^{-2} \mathrm{~h}^{-1}$ on a ground area basis. The branch enclosure data were scaled to ecosystem-level fluxes considering that the average LAI was 5.12 and assuming that the only isoprene emitter in the forest footprint is red oak, representing ca. $41 \%$ of total leaf area where the fluxes were measured, and that the reduction in isoprene emission due to inhomogeneity throughout the canopy is $25-50 \%$. To the best of our knowledge, no isoprene uptake has been reported to date.

\subsection{Isoprene oxidation products}

The major atmospheric source of MVK, MACR, and ISOPOOH is gas-phase isoprene oxidation. If there is a plant or surface sink of these compounds, a negative flux would be expected. The existence of a sink is supported by many canopy-level studies, which show deposition of MVK + $\mathrm{MACR}^{1}$ to forest canopies (Andreae et al., 2002; Karl et al., 2004, 2005, 2010), as well as by plant-level studies that suggest both surface deposition and plant uptake of these compounds may occur (Fares et al., 2015). In contrast, episodes of positive canopy fluxes of MACR + MVK have been detected at some sites (Brilli et al., 2016; Kalogridis et al., 2014; Schallhart et al., 2016; Spirig et al., 2005). These could be due to spatial gradients and inhomogeneities in isoprene oxidation or possibly to a biogenic source. To date, emission of isoprene oxidation products directly from plants has been hypothesized but rarely reported (Jardine et al., 2012).

\footnotetext{
${ }^{1}$ Previous studies reporting fluxes of MVK + MACR were actually measuring MVK + MACR + ISOPOOH (Rivera-Rios et al., 2014).
}

A plant source of these compounds could be masked at the canopy scale if there is also a plant sink.

Branch enclosure measurements of isoprene oxidation product fluxes from high isoprene emitters such as red oak are challenging due to possible interferences from the high levels of isoprene present in the enclosures during daylight. These interferences can arise from gasphase oxidation of isoprene in the sampling system or in the PTR-MS drift tube. As a result, only measurements during darkness are reported for isoprene oxidation products. For daytime, a constraint of $38 \mathrm{nmol} \mathrm{m}^{-2} \mathrm{~h}^{-1}$ could be inferred for MVK + MACR + ISOPOOH maximum emission but the actual presence of emissions could not be proved due to interferences from high levels of isoprene, as explained above. During nighttime, no net emission of MACR + MVK + ISOPOOH was detected. Deposition of MACR + MVK + ISOPOOH (Fig. 1) up to ca. $-23 \mathrm{nmol} \mathrm{m}^{-2} \mathrm{~h}^{-1}$ (Table 1) was measured during darkness on 25-28 August, when ambient air concentrations of MACR + MVK + ISOPOOH were higher than usual (up to ca. 1 ppbv). Karl et al. (2010) suggested that the uptake of MVK and MACR by vegetation occurs through stomata and is described by Fick's law. The presence of a sustained negative flux suggests plant uptake, which implies that stomata were still (partially) open at night. This is possible (Niinemets and Reichstein, 2003) and corroborated by the fact that the water vapor emission signal $(\mathrm{m} / \mathrm{z} 48.008$ in $\mathrm{NO}^{+}$mode, corresponding to $\mathrm{H}_{2} \mathrm{O} \cdot \mathrm{NO}^{+}$) remains positive at night, although decreases with respect to the daytime emission (data not shown). More insight was provided by the ancillary experiments (Table 3 and Fig. 3), in which an inverse relationship between deposition rate and MACR (or MVK) concentration is established during either day or night, consistent with Fick's law (Karl et al., 2010).

The absence of uptake saturation (Fig. 3) suggests the existence of a degradation mechanism for isoprene oxidation products inside leaves. Isoprene oxidation products are thought to be cytotoxic and their rapid removal may increase plant survival under stress conditions (Oikawa and Lerdau, 2013; Vollenweider et al., 2000). Muramoto et al. (2015) studied the uptake of MACR by tomato plants and proved that MACR concentrations up to more than $100 \mathrm{ppmv}$ are efficiently degraded by glutathionylation and enzymatic reduction within the leaves. Glutathionylation may be a more efficient mechanism for MACR removal than other hypothesized pathways, e.g., enzymatic degradation by aldehyde dehydrogenase (Karl et al., 2010; Kirch et al., 2004). Muramoto et al. (2015) identified release of isobutyraldehyde (5.8\% of the fumigated MACR) produced by reduction of MACR. Reduction of carbonyl compounds can therefore be a mechanism of detoxification of oVOC deposited to vegetation.

Contrary to MACR, the fate of MVK taken up by leaves is unknown. Interestingly, in fumigation experiments, the observed uptake of MVK was matched by an emission of MEK, 2-butanol, and 3-buten-2-ol of similar magnitude in total 

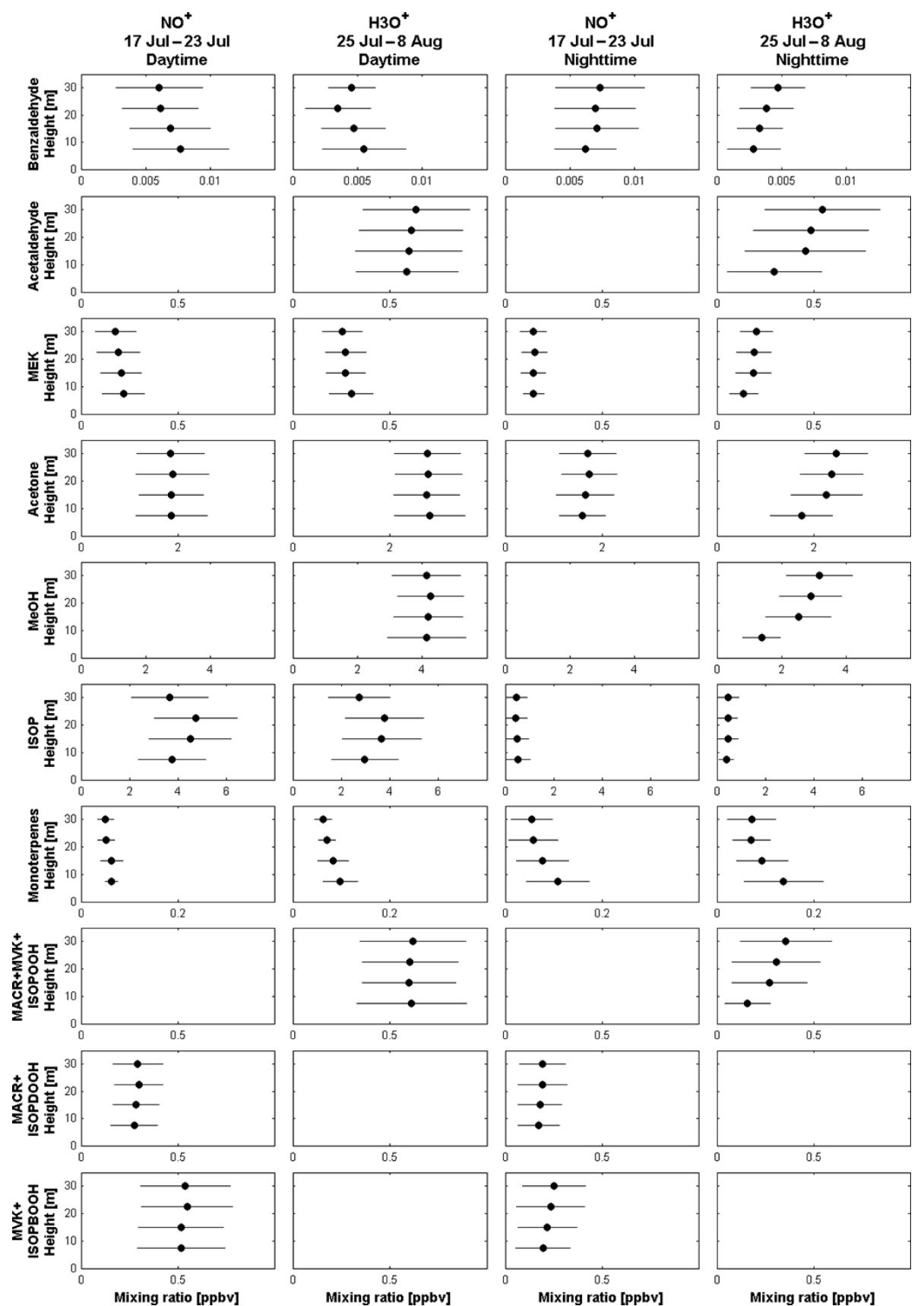

Figure 2. Average daytime and nighttime vertical concentration profiles. Measured VOC concentrations at various heights within and above canopy are reported. Horizontal bars represent standard deviations.

(see, e.g., Fig. 3). Specifically, emission of MEK accounted for $82 \pm 5 \%$ of MVK uptake, while emission of 2-butanol and 3-buten-2-ol accounted for $14 \pm 4$ and $4 \pm 1 \%$, respectively. This finding suggests complete conversions of MVK into other volatiles, predominantly MEK. A consistent explanation is enzymatic reduction. The reduction of the alkene moiety of MVK leads to MEK formation. It is hypothesized that this reduction may be catalyzed by MEK oxidoreductase, an NAD(p)-dependent enone reductase. Enzymes with enone reductase activity have been found in prokaryotes and eukaryotes, including plants (Kergomard et al., 1988; Shimoda et al., 2004; Tang and Suga, 1994; Wanner and Tressl, 1998). For instance, Wanner and Tressl (1998) purified and characterized two enone reductases from the cytosolic fraction of Saccharomyces cerevisiae and showed that they accept MVK as a substrate to form MEK. Shimoda et al. (2004) showed that cell extracts of cyanobacterium Synechococcus sp. PCC7942 reduced a variety of cyclic and acyclic enone 
Table 3. Summary of the ancillary experiments: Fumigation of forest red oak upper-canopy branches with VOCs.

\begin{tabular}{lllll}
\hline & $\begin{array}{l}\text { Henry law constant } \\
(\text { water/air }) \\
H^{\mathrm{cp}} \text { at } T^{\Theta} \\
\left(\mathrm{mol} \mathrm{m}^{-3} \mathrm{~Pa}^{-1}\right)\end{array}$ & $\begin{array}{l}\text { VOC fumigation } \\
\text { concentration range } \\
(\mathrm{ppbv})\end{array}$ & $\begin{array}{l}\text { Daytime } \\
\text { deposition }\end{array}$ & $\begin{array}{l}\text { Nighttime } \\
\text { deposition }\end{array}$ \\
\hline MVK & $2.6 \times 10^{-1}$ & $0-70$ & YES & YES \\
MACR & $4.8 \times 10^{-2}$ & $0-50$ & YES & YES \\
ISOP & $1.3 \times 10^{-4}$ & $0-700$ & - & - \\
ACETONE & $2.7 \times 10^{-1}$ & $0-70$ & - & - \\
MeOH & 2.0 & $0-70$ & YES & YES \\
\hline
\end{tabular}

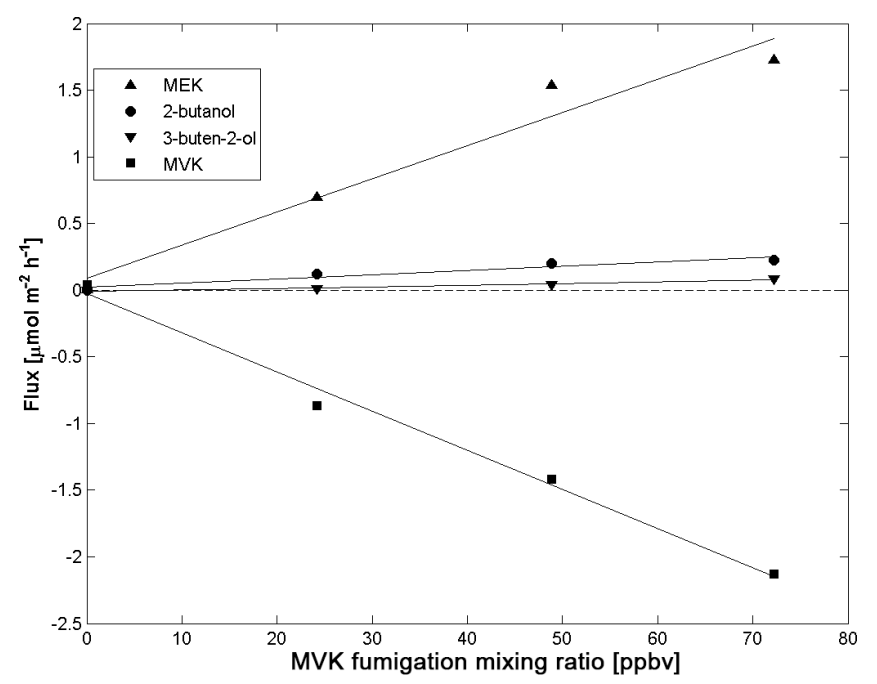

Figure 3. Example of branch-level VOC flux measured as a function of MVK fumigation mixing ratio during daytime. The concomitant MVK uptake and emission of MVK reduction products (namely MEK, 3-buten-2-ol, and 2-butanol) implies plant detoxification of MVK. Linear fit parameters are the following: $\operatorname{MEK}\left(R^{2}=0.954 ; y=0.0249 x+0.0869\right) ; 2$-butanol $\left(R^{2}=0.928\right.$; $y=0.0031 x+0.0226) ; 3$-buten-2-ol $\left(R^{2}=0.956 ; y=0.0102 x-\right.$ $0.0102)$; $\operatorname{MVK}\left(R^{2}=0.991 ; y=-0.0293 x-0.0279\right)$.

substrates, including MVK, to their corresponding alkyl ketones. Enone reductases in other organisms can also catalyze this transformation. Kergomard et al. (1988) demonstrated that unsaturated ketones were reduced by various plant cells. The formation of 3-buten-2-ol is obtained via reduction of the carbonyl moiety of MVK and 2-butanol is the result of the reduction of both the carbonyl and the alkene moiety (French, 1970). The ratio of 3-buten-2-ol to MEK emission, namely $0.05 \pm 0.02$, provides an indication of the relative importance of the two pathways (reduction of the carbonyl moiety versus reduction of the alkene moiety) for MVK detoxification.

\subsection{Methyl ethyl ketone}

Branch-level emission of MEK in red oak upper canopy ranged between 0 and $460 \mathrm{nmol} \mathrm{m}^{-2} \mathrm{~h}^{-1}$ (Tables 1, 2). Emissions peaked in the middle of the day and dropped at night. Daytime emissions averaged $40 \mathrm{nmol} \mathrm{m}^{-2} \mathrm{~h}^{-1}$, decreasing to $5 \mathrm{nmol} \mathrm{m}^{-2} \mathrm{~h}^{-1}$ at nighttime. When scaling from branch level to canopy scale under the same assumptions used in Sect. 3.1, daytime fluxes in the range $3-12 \mu \mathrm{g} \mathrm{m}^{-2} \mathrm{~h}^{-1}$ on a ground area basis can be estimated. No deposition of MEK was measured at branch level during the campaign.

Very little is known about MEK emission and deposition in forest environments. Kim et al. (2010) detected significant amounts of MEK over a Ponderosa pine forest in western Colorado during both days and nights in summer, and Karl et al. (2005) measured positive fluxes of MEK over a loblolly pine plantation. Brilli et al. (2016) reported positive and negative MEK fluxes at canopy level over a poplar plantation. In laboratory experiments, Holzinger et al. (2000) measured emission of MEK from leaves of young Quercus ilex trees in the range of $5-13 \mathrm{nmol} \mathrm{m}^{-2} \mathrm{~min}^{-1}$. MEK was also detected in fire plumes (de Gouw et al., 2006), over pasture (Kirstine et al., 1998), and over cut grass and clover (de Gouw et al., 1999). During summer 2005 and 2007, McKinney et al. (2011) measured ecosystem-scale fluxes of $\mathrm{m} / \mathrm{z} 73$ at Harvard Forest, which was attributed to MEK, with daytime emissions of $20-80 \mu \mathrm{gm}^{-2} \mathrm{~h}^{-1}$ on a ground area basis, comparable to those found in our experiments.

McKinney et al. (2011) reported slightly negative MEK fluxes during nighttime, which were not seen in our experiment on branches. Perhaps at night MEK sinks other than leaf uptake are present. Our nighttime vertical profiles of MEK (Fig. 2) show a decreasing trend with height, with MEK concentrations lower under the canopy $(0.12 \mathrm{ppbv}$ on average) than within $(0.18 \mathrm{ppbv})$ and above canopy $(0.2 \mathrm{ppbv})$. This may be consistent with a ground sink causing an ecosystem-scale negative flux of MEK during nighttime. Karl et al. (2005), measuring vertical MEK profiles within a loblolly pine plantation, also deduced a ground sink. MEK uptake in houseplants (Tani and Hewitt, 2009) and in Camellia sasanqua (Omasa et al., 2002) has been reported, 


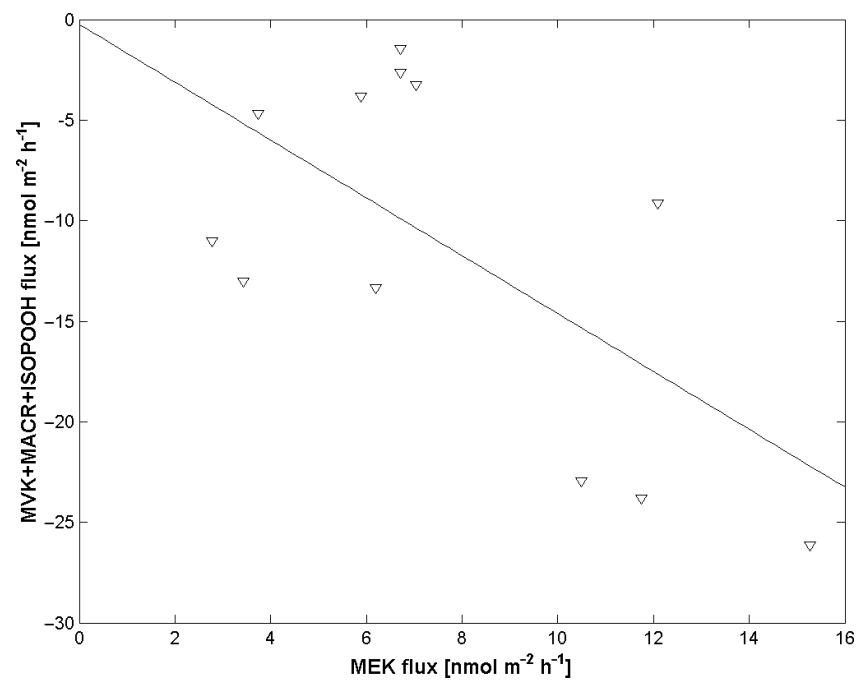

Figure 4. Scatter plot of branch-level MEK fluxes versus $\mathrm{MACR}+\mathrm{MVK}+\mathrm{ISOPOOH}$ fluxes during darkness in the period of 21-25 August. Linear fit parameters are the following: $R^{2}=$ $0.401 ; y=-1.44 x-0.24$.

although the authors noted limitations in the metabolic capacity for MEK uptake by leaf tissues (Omasa et al., 2002). In contrast, Populus nigra does not take up MEK (Omasa et al., 2000).

The metabolic pathway leading to the emission of MEK by plants is still unclear. As discussed in Sect. 3.2, MEK might be produced by MVK detoxification via enzymatic reduction. During daytime, the sources of MVK that might undergo reduction in the leaf are twofold. First, there is uptake of atmospheric MVK. Second, given the fact that Quercus rubra is a strong isoprene emitter, MVK might be produced inside the leaves upon reaction of ROS with isoprene. ROS produced upon heat stress in genetically engineered Arabidopsis and tobacco plants has been shown to react with isoprene (Velikova et al., 2008; Vickers et al., 2009) and this is thought to produce cytotoxic MVK, which may eventually be released in the atmosphere (Fares et al., 2015; Jardine et al., 2012). We have shown that MVK is detoxified into MEK, whose emission is therefore an indicator of MVK presence in leaves. As an indirect confirmation for this argument, during nighttime, when no isoprene is produced (Loreto and Sharkey, 1990), isoprene oxidation does not occur and MEK is generally not formed. Moreover, as already mentioned, nighttime deposition of MVK was occasionally observed (e.g., on 25-28 August), which should trigger MEK emission. As expected, during nighttime a significant negative correlation was found (Fig. 4; Pearson correlation coefficient $0.75 ; p<0.001$ ), with MEK emission rates not exceeding the corresponding deposition rates of MVK + MACR + ISOPOOH, which represent the upper limits for MVK uptake rates.
Due to unreliable estimates of daytime MVK uptake, a plot with daytime MEK emission (similar to Fig. 4) cannot be produced. However, maximum MVK uptake rates can be estimated from measured MVK concentrations based on the ancillary MVK fumigation experiments. For example, maximum MVK uptake rates of ca. $4 \mathrm{nmol} \mathrm{m}^{-2} \mathrm{~h}^{-1}$ can be calculated for the period 21-25 August. However, the emission rates of MEK reached about $40 \mathrm{nmol} \mathrm{m}^{-2} \mathrm{~h}^{-1}$ during this same period, suggesting a source of MEK significantly larger than the predicted uptake and reduction of atmospheric MVK. There may be different explanations for this observation. Perhaps MEK is formed by sources other than MVK or a within-plant source of MVK exists which is further detoxified to MEK and other minor products. Within-leaf oxidation of isoprene to MVK by ROS (Jardine et al., 2012) could be such a source. Interestingly, we observed a very high linear correlation between isoprene and MEK emissions during light hours (Pearson correlation coefficient in the range $0.75-0.96$ for each study period; $p<0.001$ ), which may indicate a link between MEK and isoprene formation leaves. Furthermore, during $\mathrm{H}_{3} \mathrm{O}^{+}$acquisition mode the spectral peaks at $m / 257.070$ and $m / z 55.054$, attributed to 2-butanol and 3buten-2-ol, respectively, displayed a significant correlation with MEK diel emission profile (Pearson correlation coefficients $0.97, p<0.001$, and $0.82, p<0.001$, respectively). Interference of other alcohols at $\mathrm{m} / z 57.070$ and $\mathrm{m} / z 55.054$ is possible. The ratio between 3-buten-2-ol emission and MEK emission was $0.07 \pm 0.05$ (mean ratio of total daytime emissions \pm standard deviation), comparable with the corresponding ratio found in MVK fumigation experiments $(0.05 \pm 0.02)$, indicating the relative importance of the two enzymatic reduction pathways for MVK detoxification.

\subsection{Benzaldehyde}

Both emission and deposition of benzaldehyde by uppercanopy branches were detected (Fig. 1). On average the net daily benzaldehyde exchange was positive in the period of 14-25 August, with a mean daily flux of $0.4 \mathrm{nmol} \mathrm{m}^{-2} \mathrm{~h}^{-1}$, and negative on 25 August-1 September, with a mean daily deposition rate of $-1 \mathrm{nmol} \mathrm{m}^{-2} \mathrm{~h}^{-1}$ (Table 2). Emissions of up to $2.2 \mathrm{nmol} \mathrm{m}^{-2} \mathrm{~h}^{-1}$ or $0.23 \mu \mathrm{g} \mathrm{m}^{-2} \mathrm{~h}^{-1}$ were measured, with a peak at midday (Table 1, Figs. 1 and 5). In the last two measurement periods, however, benzaldehyde was mainly deposited, at rates up to $-7 \mathrm{nmol} \mathrm{m}^{-2} \mathrm{~h}^{-1}$ or $-0.7 \mu \mathrm{g} \mathrm{m}^{-2} \mathrm{~h}^{-1}$ (Table 2), and again with a clear diel cycle. Deposition rates dropped at night but were still significant. Vertical concentration profiles in July (Fig. 2) are consistent with a canopy sink and, probably, a ground source during daytime, while nighttime profiles might indicate a canopy/ground sink.

Anthropogenic sources, such as evaporation or combustion of fossil fuels, typically have been considered the main benzenoid sources in the atmosphere (Rasmussen and Khalil, 1983). It is also formed in the atmosphere through the pho- 


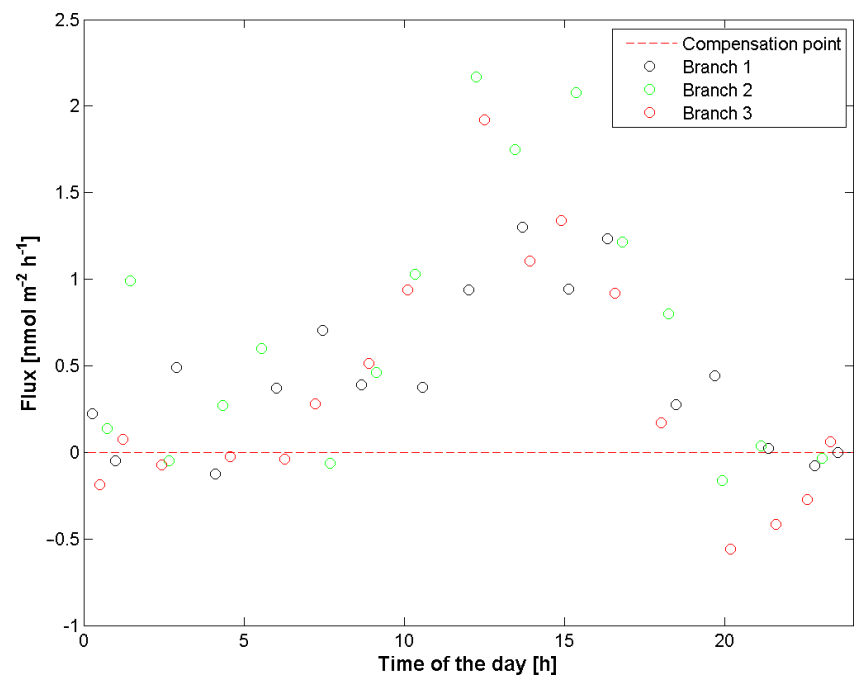

Figure 5. Example of benzaldehyde daily pattern for a day when benzaldehyde emission was detected. Measurements correspond to three different red oak upper-canopy branches.

tochemical degradation of toluene (Atkinson et al., 1980; Leone and Seinfeld, 1984) or from other precursors such as styrene and methylstyrene (Grosjean, 1985). Misztal et al. (2015) recently estimated that biogenic emissions of benzenoid compounds including benzaldehyde rival these other sources.

Benzaldehyde is an aromatic benzenoid compound naturally produced as a plant volatile (Graedel, 1978) and component of floral scents (Knudsen et al., 2006; Pichersky et al., 2006). Benzaldehyde in plants is generally synthesized from phenylalanine (Boatright et al., 2004; Dudareva et al., 2006), which is produced via the shikimate pathway (Herrmann, 1995). Emissions of benzaldehyde have been reported from Populus tremula L. $\mathrm{x}$ tremuloides Michx $\left(0.05 \mu \mathrm{g} \mathrm{m}^{-2} \mathrm{~h}^{-1}\right.$; Misztal et al., 2015), wheat (Batten et al., 1995), creosote bush (Jardine et al., 2010), and previously from red oaks (ca. $0.1 \mu \mathrm{gC} \mathrm{gdw}^{-1} \mathrm{~h}^{-1}$; Helmig et al., 1999). Emission from plants is usually associated with stress conditions. Benzaldehyde emissions have been measured upon both abiotic (heat) and biotic (herbivore feeding) stresses (Misztal et al., 2015).

A linear relationship between benzaldehyde deposition flux and benzaldehyde concentration in the branch enclosures (Fig. 6) indicates benzaldehyde exchange is regulated according to Fick's law (Karl et al., 2010; Omasa et al., 2002). Uptake of benzaldehyde by stomata has been suggested in houseplants (Tani and Hewitt, 2009). Daytime uptake rates of benzaldehyde suggest the existence of a compensation point (Fig. 6) of around 0.02-0.025 ppbv. Further studies in controlled conditions would be needed to confirm the presence of a compensation point and to elucidate its dependence on environmental and physiological parameters. Further investigations are also required to explain why benzaldehyde is deposited. Early studies demonstrated that ben-

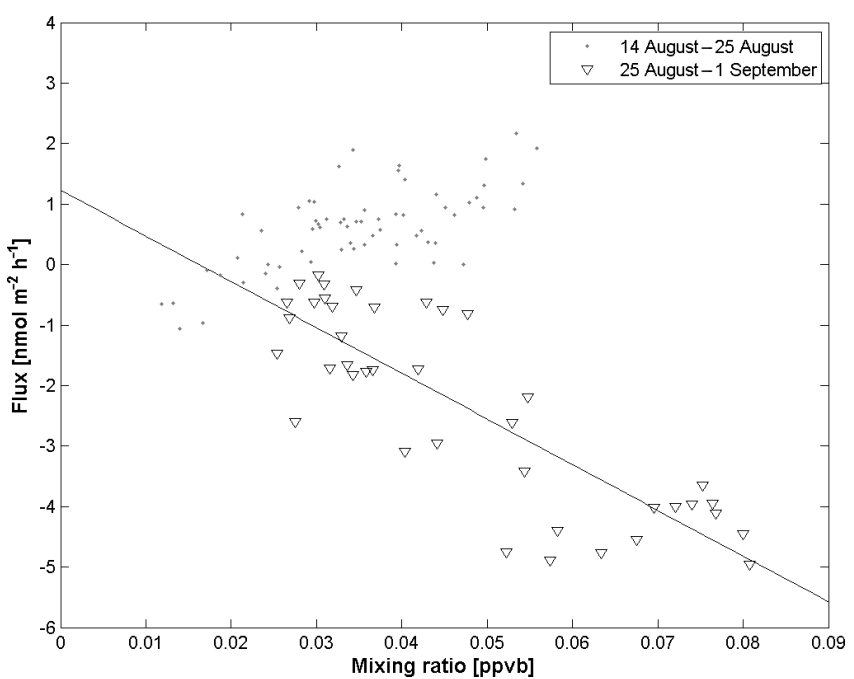

Figure 6. Flux measured as a function of mixing ratio for benzaldehyde during daytime of the whole branch-level measurement campaign. Black triangles represent the period of 25 August-1 September, when deposition dominated, and grey dots correspond to the period of 14-25 August, where mostly emission was measured. Linear fit parameters are the following: $R^{2}=0.701 ; y=-75.59 x+1.22$.

zenoid compounds such as benzene and toluene may be assimilated by crop plants grown under sterile conditions via aromatic ring cleavage and successive incorporation of their carbon atoms into nonvolatile organic acids or amino acids (Durmishidze, 1975; Ugrekhelidze et al., 1997; Ugrekhelidze, 1976).

Figure 6 also shows that benzaldehyde emissions were detected during the first measurement period when deposition would be expected on the basis of its gas-phase mixing ratio. As mentioned, benzaldehyde emissions from leaves are typically associated with stress conditions (Misztal et al., 2015). This might have been the case, even though it was not possible to determine whether a stress was the driving factor.

\subsection{Acetaldehyde}

Bidirectional exchange of acetaldehyde was observed (Fig. 1, Tables 1, 2), with the strongest emissions (up to $170 \mathrm{nmol} \mathrm{m}^{-2} \mathrm{~h}^{-1}$ on a leaf area basis) occurring in the middle of the day. Significant acetaldehyde deposition occurred mostly in the afternoon in the period 25-28 August, with uptake rates up to $-40 \mathrm{nmol} \mathrm{m}^{-2} \mathrm{~h}^{-1}$. Vertical acetaldehyde profiles from the period 25 July- 8 August show a decrease in nighttime acetaldehyde concentrations going from above canopy to below canopy (Fig. 2), suggesting a forest sink of acetaldehyde during nighttime, although the nature of the sink deserves further investigation.

Acetaldehyde uptake by plant canopies from the atmosphere occurs primarily via stomata (Karl et al., 2005; Rottenberger et al., 2004) whereas surface deposition is minor (Jardine et al., 2008). Kondo et al. (1998) demonstrated that 
a biological sink for acetaldehyde should exist within plants since they are capable of continuous uptake for as long as $8 \mathrm{~h}$ even under ambient acetaldehyde concentrations exceeding 200 ppbv.

Jardine et al. (2008) demonstrated that acetaldehyde exchange rates are controlled by ambient acetaldehyde concentrations, stomata resistance to acetaldehyde, and acetaldehyde compensation point, which suggests a plant source as well as a sink. The cause of acetaldehyde emissions from plants remains elusive. Acetaldehyde might be formed in leaves from ethanol translocated from roots, especially when anoxic conditions prevent root respiration (Kreuzwieser et al., 1999) or from cytosolic pyruvate, e.g., after darkening (Karl et al., 2002a) or wounding (Loreto et al., 2006). In the period of study, we report net acetaldehyde emission from the upper-canopy branches, which may be due to any of these sources.

The measured bidirectional flux of acetaldehyde implies a compensation point in the range of $0-3$ ppbv. During transitions from emission to uptake (e.g., on 25-28 August) the value was better constrained to $1-2 \mathrm{ppbv}$. The acetaldehyde compensation point seems to increase with increasing light intensity as might be deduced comparing light intensity, acetaldehyde mixing ratios, and fluxes (see, e.g., Fig. 1, 25-28 August). This might imply a light control on acetaldehyde exchange in the field, in line with the findings of Jardine et al. (2008) in laboratory experiments.

\subsection{Acetone}

A great variety of plants have constitutive emissions of acetone (Bracho-Nunez et al., 2013; Isidorov et al., 1985). High acetone concentrations have been reported above several forests (e.g., Geron et al., 2002; Helmig et al., 1998; Karl et al., 2003; Müller et al., 2006; Pöschl et al., 2001), tree plantations (Brilli et al., 2014b), and after biomass fires (Brilli et al., 2014a). Red oaks also emit acetone (Steinbrecher et al., 2009). In our branch-scale measurements acetone emission reached $340 \mathrm{nmol} \mathrm{m}^{-2} \mathrm{~h}^{-1}$ on a leaf area basis (Table 1). A diel cycle was found with average daytime emissions of $70 \mathrm{nmol} \mathrm{m}^{-2} \mathrm{~h}^{-1}$. Emission dropped at night to an average of $15 \mathrm{nmol} \mathrm{m}^{-2} \mathrm{~h}^{-1}$. Similar diel patterns of acetone emissions, i.e., displaying mid-day emission maxima, have been reported in several canopy-scale experiments (Goldstein and Schade, 2000; Karl et al., 2003, 2002b; Rinne et al., 2007; Schade and Goldstein, 2001).

The branch-scale measurements can be scaled up to daytime average canopy-scale fluxes of about ca. 20$40 \mu \mathrm{g} \mathrm{m}^{-2} \mathrm{~h}^{-1}$ on a ground area basis. In this case, the assumptions for scaling the data to ecosystem-level fluxes were that red oak leaves emit acetone homogenously throughout the canopy, that average LAI was $=5.2$, and that all tree species in the forest emit acetone at the same rate. These values are consistent with the measurements of McKinney et al. (2011) at Harvard Forest, who observed average daytime canopy-scale acetone fluxes between 20 and $40 \mu \mathrm{g} \mathrm{m}^{-2} \mathrm{~h}^{-1}$ on a ground area basis in 2007 and a factor of 5 higher in 2005. The scaling of measured branch-level fluxes to canopy level assumes that the only contribution to the flux is from tree branches, while other possible sources and sinks, such as the soil or chemistry within the canopy, are neglected. This should be kept in mind when comparing the predicted canopy-scale fluxes to the measured eddy covariance fluxes. Some insight into the possible soil contribution to fluxes is provided by the concentration vertical profile data discussed below.

Dependence of biogenic acetone emission on temperature has been consistently reported (Bracho-Nunez et al., 2013; Cojocariu et al., 2004; Grabmer et al., 2006; Janson and de Serves, 2001; Schade and Goldstein, 2001), whereas the relationships with light and stomata conductance are less clear (Bracho-Nunez et al., 2013; Cojocariu et al., 2004; Filella et al., 2009). However, relative humidity is believed to have a negative influence on acetone canopy fluxes (McKinney et al., 2011). Indications in the same direction have been found by Cojocariu et al. (2004) by studying acetone emissions from Picea abies. The metabolic mechanisms leading to acetone release have not yet been proven. At present, no processbased model is capable of reliably describing biogenic acetone emissions. Selected plants decompose cyanogenic glucosides to generate acetone cyanohydrin, which is metabolized by a lyase to form hydrogen cyanide and acetone (Fall, 2003; Gruber et al., 2004). Decarboxylation of acetoacetate is another mechanism that has been hypothesized for acetone production (Macdonald and Fall, 1993).

McKinney et al. (2011) reported several events of negative fluxes of acetone (up to $-50 \mu \mathrm{g} \mathrm{m}^{-2} \mathrm{~h}^{-1}$ ), especially at night and in the early morning. Several other studies have also reported negative acetone night fluxes at canopy scale (Karl et al., 2004, 2005). Winters et al. (2009) reported a negative correlation between emission rates and ambient concentration that also suggests a bidirectional acetone exchange. Moreover, at leaf level Cojocariu et al. (2004) reported events of acetone uptake during darkness. In principle plant uptake of acetone is a possible explanation. There are very limited literature studies supporting this hypothesis, however. Furthermore, as pointed out by Cojocariu et al. (2004), there is no known mechanism for acetone uptake within plants. In fact, plant fumigation in controlled environments generally does not result in acetone uptake (see, e.g., Omasa et al., 2002). Only transient episodes of acetone uptake were reported by Tani and Hewitt (2009) which can be explained by solubility of acetone in the water content inside the leaf, not followed by metabolization or translocation. Consistent with these results, no episodes of branch-scale acetone deposition were detected during our campaign. Furthermore, in the ancillary experiments, when upper-canopy red oak branches were fumigated with acetone, no acetone uptake was detected (Table 3), despite acetone fumigation concentrations as high as ca. 70 ppbv. These results suggest negative canopy-level 
fluxes of acetone may be due to a mechanism other than stomatal uptake. The vertical profiles (Fig. 2) indicate nighttime acetone concentrations in the range of $1-3$ ppbv, with a decreasing trend from above to below canopy. As in the case of MEK, this may suggest a ground sink of acetone at night. This hypothesis should be verified in future experiments.

\subsection{Methanol}

Methanol production by vegetation is known to be related to growth and tissue repair processes. It is produced from the demethylation of membrane pectins during formation of cell walls (Fall, 2003; Fall and Benson, 1996). Long-term methanol monitoring (Schade and Goldstein, 2006) shows methanol emission peaks during spring in conjunction with the rapid growing of leaves. Hence, growth rate is a key factor controlling plant methanol emission as it strongly influences internal production rate within the plant (Harley et al., 2007; Hüve et al., 2007). Additional drivers of methanol emissions include temperature and stomatal conductance (Harley et al., 2007; Hüve et al., 2007). While in the case of acetaldehyde stomata exert long-term control on emission rates (Jardine et al., 2008), stomatal limitations on methanol emissions are short-term. As methanol (as well as other oVOCs) is more soluble in water than non-oxygenated VOCs, it builds up liquid foliar pools that result in a constant flux out of the leaf despite stomatal movements (Niinemets and Reichstein, 2003).

During the campaign, methanol emissions from red oak upper-canopy branches were up to $3000 \mathrm{nmol} \mathrm{m}^{-2} \mathrm{~h}^{-1}$ on a leaf area basis (Table 1). Emissions peaked during the day and dropped at night to an average of $300 \mathrm{nmol} \mathrm{m}^{-2} \mathrm{~h}^{-1}$. Scaling up the branch-level data (August 2014) to the ecosystem scale using the same assumptions as for acetone, the resulting daytime (10:00-15:00 h) methanol fluxes range between ca. 200 and $400 \mu \mathrm{g} \mathrm{m}^{-2} \mathrm{~h}^{-1}$ on a ground area basis. This is in good agreement with canopy-level flux measurements in the same forest by McKinney et al. (2011), who reported daytime ecosystem-scale fluxes of ca. 100$400 \mu \mathrm{g} \mathrm{m}^{-2} \mathrm{~h}^{-1}$ on a ground area basis in July 2007 and also observed a similar diel emission pattern. Based on the branch-level experiments, the net $24 \mathrm{~h}$ average methanol exchange was $650 \mathrm{nmol} \mathrm{m}^{-2} \mathrm{~h}^{-1}$ on a leaf area basis or $3400 \mathrm{nmol} \mathrm{m}^{-2} \mathrm{~h}^{-1}$ on a ground area basis. At a Missouri Ozark mixed forest, Seco et al. (2015) measured a net ecosystem flux of ca. $2500 \mathrm{nmol} \mathrm{m}^{-2} \mathrm{~h}^{-1}$ (May through October). Laffineur et al. (2012) studied methanol exchange in the mixed forest of Vielsalm (Belgium) and found a negative average net ecosystem flux (ca. $-350 \mathrm{nmol} \mathrm{m}^{-2} \mathrm{~h}^{-1}$; July through October).

No methanol deposition was observed at branch scale during the campaign. The ancillary experiments (Table 3, Fig. 7) show that for the same branches methanol deposition occurs when ambient concentration is rather high. Methanol compensation points in our data were ca. 15-20 ppbv at night and ca. 25-45 ppbv during the day (Fig. 7). However, throughout

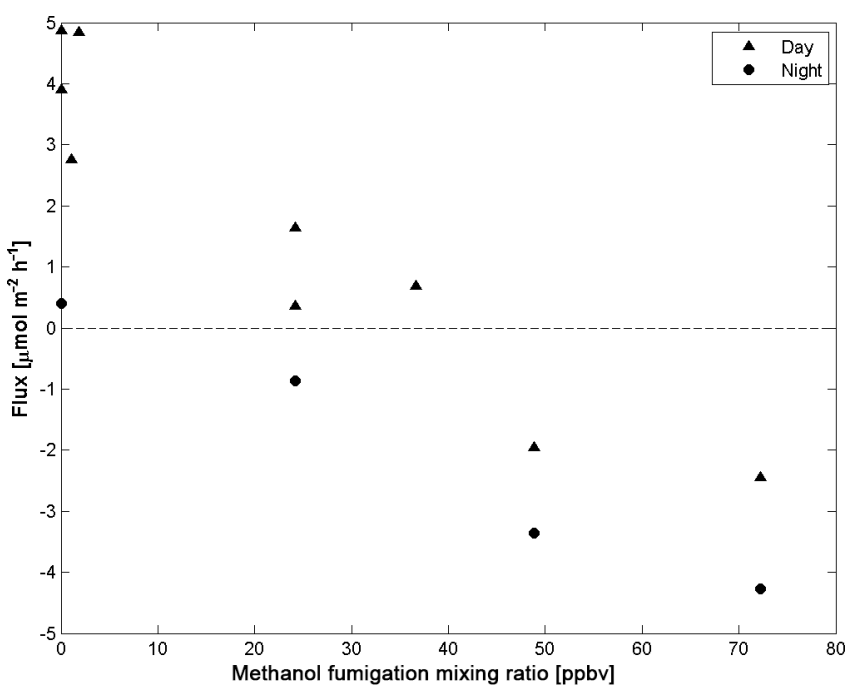

Figure 7. Example of enclosure flux measured as a function of fumigation mixing ratio for methanol in the field.

the campaign ambient methanol mixing ratios did not exceed 10 ppbv (Fig. 1), which explains why no uptake was observed under ambient conditions. McKinney et al. (2011) reported near-zero methanol fluxes at Harvard Forest during night, although methanol uptake events were detected, often in the early morning. Vertical profiles of methanol concentrations (Fig. 2) are consistent with a methanol source within the canopy during daytime while at nighttime the lowest layer displays a significantly lower concentration than the upper layers. This might indicate a lower-canopy/ground nighttime methanol sink.

In the fumigation experiments, methanol deposition is not transient and a compensation point is present (Fig. 7), suggesting the existence of a methanol degradation mechanism. Likewise, many studies have reported significant canopyscale methanol deposition to vegetation or soil and evidence of bidirectional exchange (Wohlfahrt et al., 2012), but a holistic mechanistic explanation is lacking. Other studies suggest that methanol is taken up by stomata. For example, Gout (2000) reported stomatal uptake followed by oxidation of methanol producing formaldehyde. Given the similar uptake rates found during day and night (Fig. 7), this would imply that stomata were still (partially) open at night (Niinemets and Reichstein, 2003). As already mentioned, this is corroborated by the fact that the water vapor emissions remain positive at night, although lower than daytime emissions (data not shown). Another possibility is the consumption of methanol by microorganisms that are commonly found on leaves (Holland and Polacco, 1994) and are able to degrade it via enzymatic reactions, e.g., methylotrophic bacteria (Duine and Frank, 1980). A further hypothesis is chemical transformation of methanol dissolved in water films on leaf surfaces, e.g., via reaction with $\mathrm{OH}$ radicals (Elliot and McCracken, 1989). 


\subsection{Monoterpenes}

Although isoprene is by far the most abundant isoprenoid emitted by red oaks, monoterpene emission may also be found. In previous branch enclosure studies, Kim et al. (2011) and Helmig et al. (1999) both detected monoterpene emissions from red oaks amounting to about $1.1 \%$ of total isoprenoids, though with slightly different monoterpene compositions. In our experiment, the daytime monoterpenes / total isoprenoids ratio was in the range of 0.04 $0.25 \%\left(\mu \mathrm{g} \mathrm{m}^{-2} \mathrm{~s}^{-1} / \mu \mathrm{g} \mathrm{m}^{-2} \mathrm{~s}^{-1}\right)$, which is about an order of magnitude lower than in previous studies.

In the literature, plant species are considered to emit either isoprene or monoterpenes (Harrison et al., 2013), which indicates a possible trade-off of available carbon among isoprenoids (Dani et al., 2015). However, there are important exceptions. First, there are families that actually emit both isoprenoids, although only monoterpenes are stored in permanent pools (Loreto and Fineschi, 2015). Second, emissions of isoprene and monoterpenes in the same plants may occur at different developmental stages. In general, monoterpenes are emitted by young, expanding leaves that upon maturation produce and emit only isoprene. For example, Picea abies switches from emitting monoterpenes during May (Schürmann et al., 1993) to predominantly isoprene in June and sesquiterpenes in July (Hakola et al., 2003). Young leaves of several species of poplars (Populus sp) emit monoterpenes before complete expansion, when isoprene emission gradually replaces monoterpenes (Brilli et al., 2009; Hakola et al., 1998). Emissions of monoterpenes by red oaks in our branch experiments may therefore indicate the presence of young, growing leaves.

Oaks emitting large amounts of monoterpenes have been described and are generally evergreen species living in Mediterranean conditions (Loreto et al., 1998, 2009). These oaks do not store monoterpenes in permanent pools and therefore emit monoterpenes in an isoprene-like fashion, with similar light and temperature dependence (Loreto et al., 1996). We measured daytime emission of monoterpenes with a diurnal cycle very similar to that of isoprene (Fig. 1), and a highly significant correlation is present between daytime isoprene and monoterpene emissions (Pearson correlation coefficient $0.88, p<0.05)$. This suggests de novo monoterpene biosynthesis (Loreto et al., 1996), also in a predominantly isoprene-emitting temperate oak. However, in our experiment monoterpene emissions were also detected during nighttime (Tables 1 and 2), with average rates of 2 $20 \mathrm{nmol} \mathrm{m}^{-2} \mathrm{~h}^{-1}$, suggesting at least some emission from stored pools.

Finally, monoterpene deposition was found on only one out of the three branches sampled (Table 2). By analogy with the much larger emissions of isoprene where deposition was not observed, it may be suggested that monoterpene deposition may be rare or absent.

\section{Conclusions}

The observations presented herein provide new information about the bidirectional exchange of oVOCs between forest plants and the atmosphere. In the predominantly isopreneemitting red oaks that were the subject of our investigation, we found a link between exchanges of MVK and MEK, which provides a new framework for the understanding of MEK exchange, based on a possible in-plant source from isoprene oxidation products. This link supports the hypothesis of plant stress defense by isoprene via reaction with ROS. Production of MEK in excess of MVK uptake and in correlation with isoprene emission suggests within-plant oxidation of isoprene to MVK followed by detoxification and the eventual release of volatile products such as MEK, 3-buten2-ol and 2-butanol. Further studies are needed to confirm this link. We also found small emissions of monoterpenes, which might be a marker of juvenility in the canopy. We report bidirectional exchange of benzaldehyde between biosphere and the atmosphere, describing a so far unknown (to our knowledge) foliar deposition of benzenoid compounds. More investigations on benzenoid bidirectional exchange are needed to improve global budgets of the biogenic and anthropogenic sources of these volatiles. Emissions and fluxes of other important oVOCs such as acetaldehyde, methanol, and acetone have been confirmed.

Data availability. The full dataset is available from the authors upon request (email). Data will also be available on the Harvard Forest archive.

\section{The Supplement related to this article is available online at doi:10.5194/acp-17-4189-2017-supplement.}

Author contributions. L. Cappellin and K. McKinney designed this research; field work was carried out by L. Cappellin, A. Algarra Alarcon, I. Herdlinger-Blatt, J. Sanchez, and K. McKinney. Laboratory analyses were performed by A. Algarra Alarcon and L. Cappellin. L. Cappellin, F. Biasioli, S. Martin, F. Loreto, and K. McKinney wrote the paper.

Competing interests. The authors declare that they have no conflict of interest.

Acknowledgements. Luca Cappellin acknowledges funding from H2020-EU.1.3.2 (grant agreement n. 659315). The authors thank Evan Goldman and J. William Munger for providing LAI data and Mark Vanscoy for providing meteorological data and for managing the measurement site.

Edited by: J. Rinne

Reviewed by: two anonymous referees 


\section{References}

Andreae, M. O., Artaxo, P., Brandão, C., Carswell, F. E., Ciccioli, P., da Costa, A. L., Culf, A. D., Esteves, J. L., Gash, J. H. C., Grace, J., Kabat, P., Lelieveld, J., Malhi, Y., Manzi, A. O., Meixner, F. X., Nobre, A. D., Nobre, C., Ruivo, M. d. L. P., Silva-Dias, M. A., Stefani, P., Valentini, R., von Jouanne, J., and Waterloo, M. J.: Biogeochemical cycling of carbon, water, energy, trace gases, and aerosols in Amazonia: The LBA-EUSTACH experiments, J. Geophys. Res.-Atmos., 107, 8066, doi:10.1029/2001JD000524, 2002.

Atkinson, R.: Atmospheric chemistry of VOCs and $\mathrm{NO}_{x}$, Atmos. Environ., 34, 2063-2101, doi:10.1016/S1352-2310(99)00460-4, 2000.

Atkinson, R. and Arey, J.: Atmospheric Chemistry of Biogenic Organic Compounds, Acc. Chem. Res., 31, 574-583, doi:10.1021/ar970143z, 1998.

Atkinson, R., Carter, W. P. L., Darnall, K. R., Winer, A. M., and Pitts, J. N.: A smog chamber and modeling study of the gas phase $\mathrm{NO}_{x}$-air photooxidation of toluene and the cresols, Int. J. Chem. Kinet., 12, 779-836, doi:10.1002/kin.550121102, 1980.

Baeza Romero, M. T., Blitz, M. A., Heard, D. E., Pilling, M. J., Price, B., Seakins, P. W., and Wang, L.: Photolysis of methylethyl, diethyl and methylvinyl ketones and their role in the atmospheric $\mathrm{HO}_{x}$ budget, Faraday Discuss., 130, 73-88, doi:10.1039/B419160A, 2005.

Batten, J. H., Stutte, G. W., and Wheeler, R. M.: Effect of crop development on biogenic emissions from plant populations grown in closed plant growth chambers, Phytochemistry, 39, 13511357, 1995.

Benkovitz, C. M., Schwartz, S. E., Jensen, M. P., Miller, M. A., Easter, R. C., and Bates, T. S.: Modeling atmospheric sulfur over the Northern Hemisphere during the Aerosol Characterization Experiment 2 experimental period, J. Geophys. Res.-Atmos., 109, D22207, doi:10.1029/2004JD004939, 2004.

Boatright, J., Negre, F., Chen, X., Kish, C. M., Wood, B., Peel, G., Orlova, I., Gang, D., Rhodes, D., and Dudareva, N.: Understanding in Vivo Benzenoid Metabolism in Petunia Petal Tissue, Plant Physiol., 135, 1993-2011, doi:10.1104/pp.104.045468, 2004.

Boose, E.: Fisher Meteorological Station (since 2001) [Data set], Harvard Forest, doi:10.6073/AA/KNB-LTER-HFR.1.2, 2001.

Bouvier-Brown, N. C., Goldstein, A. H., Worton, D. R., Matross, D. M., Gilman, J. B., Kuster, W. C., Welsh-Bon, D., Warneke, C., de Gouw, J. A., Cahill, T. M., and Holzinger, R.: Methyl chavicol: characterization of its biogenic emission rate, abundance, and oxidation products in the atmosphere, Atmos. Chem. Phys., 9, 2061-2074, doi:10.5194/acp-9-2061-2009, 2009.

Bracho-Nunez, A., Knothe,, N. M., Welter, S., Staudt, M., Costa, W. R., Liberato, M. A. R., Piedade, M. T. F., and Kesselmeier, J.: Leaf level emissions of volatile organic compounds (VOC) from some Amazonian and Mediterranean plants, Biogeosciences, 10, 5855-5873, doi:10.5194/bg-10-5855-2013, 2013.

Brilli, F., Ciccioli, P., Frattoni, M., Prestininzi, M., Spanedda, A. F., and Loreto, F.: Constitutive and herbivore-induced monoterpenes emitted by Populus x euroamericana leaves are key volatiles that orient Chrysomela populi beetles, Plant Cell Environ., 32, 542552, doi:10.1111/j.1365-3040.2009.01948.x, 2009.

Brilli, F., Gioli, B., Ciccioli, P., Zona, D., Loreto, F., Janssens, I. A., and Ceulemans, R.: Proton Transfer Reaction Time-of-Flight Mass Spectrometric (PTR-TOF-MS) determination of volatile organic compounds (VOCs) emitted from a biomass fire developed under stable nocturnal conditions, Atmos. Environ., 97, 5467, doi:10.1016/j.atmosenv.2014.08.007, 2014a.

Brilli, F., Gioli, B., Zona, D., Pallozzi, E., Zenone, T., Fratini, G., Calfapietra, C., Loreto, F., Janssens, I. A., and Ceulemans, R.: Simultaneous leaf- and ecosystem-level fluxes of volatile organic compounds from a poplar-based SRC plantation, Agr. Forest Meteorol., 187, 22-35, doi:10.1016/j.agrformet.2013.11.006, 2014 b.

Brilli, F., Gioli, B., Fares, S., Terenzio, Z., Zona, D., Gielen, B., Loreto, F., Janssens, I. A., and Ceulemans, R.: Rapid leaf development drives the seasonal pattern of volatile organic compound (VOC) fluxes in a "coppiced" bioenergy poplar plantation, Plant Cell Environ., 39, 539-555, doi:10.1111/pce.12638, 2016.

Carlton, A. G., Wiedinmyer, C., and Kroll, J. H.: A review of Secondary Organic Aerosol (SOA) formation from isoprene, Atmos. Chem. Phys., 9, 4987-5005, doi:10.5194/acp-9-4987-2009, 2009.

Claeys, M., Graham, B., Vas, G., Wang, W., Vermeylen, R., Pashynska, V., Cafmeyer, J., Guyon, P., Andreae, M. O., Artaxo, P., and Maenhaut, W.: Formation of Secondary Organic Aerosols Through Photooxidation of Isoprene, Science, 303, 1173-1176, doi:10.1126/science.1092805, 2004.

Cojocariu, C., Kreuzwieser, J., and Rennenberg, H.: Correlation of short-chained carbonyls emitted from Picea abies with physiological and environmental parameters, New Phytol., 162, 717727, doi:10.1111/j.1469-8137.2004.01061.x, 2004.

Dani, K. G. S., Fineschi, S., and Loreto, F.: Biogenic Volatile Isoprenoid Emission and Levels of Natural Selection, J. Indian Inst. Sci., 95, 1-14, 2015.

de Gouw, J. A., Howard, C. J., Custer, T. G., and Fall, R.: Emissions of volatile organic compounds from cut grass and clover are enhanced during the drying process, Geophys. Res. Lett., 26, 811-814, doi:10.1029/1999GL900076, 1999.

de Gouw, J. A., Warneke, C., Stohl, A., Wollny, A. G., Brock, C. A., Cooper, O. R., Holloway, J. S., Trainer, M., Fehsenfeld, F. C., Atlas, E. L., Donnelly, S. G., Stroud, V., and Lueb, A.: Volatile organic compounds composition of merged and aged forest fire plumes from Alaska and western Canada, J. Geophys. Res.-Atmos., 111, D10303, doi:10.1029/2005JD006175, 2006.

Dudareva, N., Negre, F., Nagegowda, D. A., and Orlova, I.: Plant Volatiles: Recent Advances and Future Perspectives, Crit. Rev. Plant Sci., 25, 417-440, doi:10.1080/07352680600899973, 2006.

Duine, J. A. and Frank, J.: The prosthetic group of methanol dehydrogenase. Purification and some of its properties, Biochem. J., 187, 221-226, 1980.

Durmishidze, S. V.: Cleavage of the Aromatic Ring of Some Exogenous Compounds in Plants, Metsniereba, Tbilisi, 1975.

Elliot, A. J. and McCracken, D. R.: Effect of temperature on O $\oslash$ reactions and equilibria: A pulse radiolysis study, Int. J. Radiat. Appl. Instrum. Part C Radiat. Phys. Chem., 33, 69-74, doi:10.1016/1359-0197(89)90096-9, 1989.

Fall, R.: Abundant oxygenates in the atmosphere: a biochemical perspective, Chem. Rev., 103, 4941-4952, doi:10.1021/cr0206521, 2003.

Fall, R. and Benson, A. A.: Leaf methanol - the simplest natural product from plants, Trends Plant Sci., 1, 296-301, doi:10.1016/S1360-1385(96)88175-0, 1996. 
Fares, S., Paoletti, E., Loreto, F., and Brilli, F.: Bidirectional Flux of Methyl Vinyl Ketone and Methacrolein in Trees with Different Isoprenoid Emission under Realistic Ambient Concentrations, Environ. Sci. Technol., 49, 7735-7742, doi:10.1021/acs.est.5b00673, 2015.

Filella, I., Peñuelas, J., and Seco, R.: Short-chained oxygenated VOC emissions in Pinus halepensis in response to changes in water availability, Acta Physiol. Plant., 31, 311-318, doi:10.1007/s11738-008-0235-6, 2009.

French, E. C.: The Electrochemical Reduction of Methyl Vinyl Ketone in Aqueous Solutions, North Texas State University, 1970.

Galbally, I. E. and Kirstine, W.: The Production of Methanol by Flowering Plants and the Global Cycle of Methanol, J. Atmos. Chem., 43, 195-229, doi:10.1023/A:1020684815474, 2002.

Geron, C., Guenther, A., Greenberg, J., Loescher, H. W., Clark, D., and Baker, B.: Biogenic volatile organic compound emissions from a lowland tropical wet forest in Costa Rica, Atmos. Environ., 36, 3793-3802, doi:10.1016/S1352-2310(02)00301-1, 2002.

Goldstein, A. H. and Galbally, I. E.: Known and Unexplored Organic Constituents in the Earth's Atmosphere, Environ. Sci. Technol., 41, 1514-1521, doi:10.1021/es072476p, 2007.

Goldstein, A. H. and Schade, G. W.: Quantifying biogenic and anthropogenic contributions to acetone mixing ratios in a rural environment, Atmos. Environ., 34, 4997-5006, doi:10.1016/S13522310(00)00321-6, 2000.

Gout, E.: Metabolism of Methanol in Plant Cells. Carbon-13 Nuclear Magnetic Resonance Studies, Plant Physiol., 123, 287-296, doi:10.1104/pp.123.1.287, 2000.

Grabmer, W., Kreuzwieser, J., Wisthaler, A., Cojocariu, C., Graus, M., Rennenberg, H., Steigner, D., Steinbrecher, R., and Hansel, A.: VOC emissions from Norway spruce (Picea abies L. [Karst]) twigs in the field - Results of a dynamic enclosure study, Atmos. Environ., 40, Supplement 1, 128-137, doi:10.1016/j.atmosenv.2006.03.043, 2006.

Graedel, T. E.: Chemical compounds in the atmosphere, Academic Press, New York, 1978.

Griffin, R. J., Cocker, D. R., Flagan, R. C., and Seinfeld, J. H.: Organic aerosol formation from the oxidation of biogenic hydrocarbons, J. Geophys. Res.-Atmos., 104, 3555-3567, doi:10.1029/1998JD100049, 1999.

Grosjean, D.: Atmospheric reactions of styrenes and peroxybenzoyl nitrate, Sci. Total Environ., 46, 41-59, doi:10.1016/00489697(85)90282-7, 1985.

Gruber, K., Gartler, G., Krammer, B., Schwab, H., and Kratky, C.: Reaction mechanism of hydroxynitrile lyases of the alpha/beta-hydrolase superfamily: the three-dimensional structure of the transient enzyme-substrate complex certifies the crucial role of LYS236, J. Biol. Chem., 279, 20501-20510, doi:10.1074/jbc.M401575200, 2004.

Guenther, A.: The contribution of reactive carbon emissions from vegetation to the carbon balance of terrestrial ecosystems, Chemosphere, 49, 837-844, doi:10.1016/S00456535(02)00384-3, 2002.

Guenther, A., Hewitt, C. N., Erickson, D., Fall, R., Geron, C., Graedel, T., Harley, P., Klinger, L., Lerdau, M., Mckay, W. A., Pierce, T., Scholes, B., Steinbrecher, R., Tallamraju, R., Taylor, J., and Zimmerman, P.: A global model of natural volatile organic compound emissions, J. Geophys. Res.-Atmos., 100, 8873-8892, doi:10.1029/94JD02950, 1995.

Guenther, A., Karl, T., Harley, P., Wiedinmyer, C., Palmer, P. I., and Geron, C.: Estimates of global terrestrial isoprene emissions using MEGAN (Model of Emissions of Gases and Aerosols from Nature), Atmos. Chem. Phys., 6, 3181-3210, doi:10.5194/acp-63181-2006, 2006.

Hakola, H., Rinne, J., and Laurila, T.: The hydrocarbon emission rates of tea-leafed willow (Salix phylicifolia), silver birch (Betula pendula) and European aspen (Populus tremula), Atmos. Environ., 32, 1825-1833, doi:10.1016/S1352-2310(97)00482-2, 1998.

Hakola, H., Tarvainen, V., Laurila, T., Hiltunen, V., Hellén, H., and Keronen, P.: Seasonal variation of VOC concentrations above a boreal coniferous forest, Atmos. Environ., 37, 1623-1634, doi:10.1016/S1352-2310(03)00014-1, 2003.

Harley, P., Greenberg, J., Niinemets, Ü., and Guenther, A.: Environmental controls over methanol emission from leaves, Biogeosciences, 4, 1083-1099, doi:10.5194/bg-4-1083-2007, 2007.

Harrison, S. P., Morfopoulos, C., Dani, K. G. S., Prentice, I. C., Arneth, A., Atwell, B. J., Barkley, M. P., Leishman, M. R., Loreto, F., Medlyn, B. E., Niinemets, Ü., Possell, M., Peñuelas, J., and Wright, I. J.: Volatile isoprenoid emissions from plastid to planet, New Phytol., 197, 49-57, doi:10.1111/nph.12021, 2013.

Heiden, A. C., Kobel, K., Komenda, M., Koppmann, R., Shao, M., and Wildt, J.: Toluene emissions from plants, Geophys. Res. Lett., 26, 1283-1286, doi:10.1029/1999GL900220, 1999.

Helmig, D., Balsley, B., Davis, K., Kuck, L. R., Jensen, M., Bognar, J., Smith, T., Arrieta, R. V., Rodríguez, R., and Birks, J. W.: Vertical profiling and determination of landscape fluxes of biogenic nonmethane hydrocarbons within the planetary boundary layer in the Peruvian Amazon, J. Geophys. Res.-Atmos., 103, 25519 25532, doi:10.1029/98JD01023, 1998.

Helmig, D., Klinger, L. F., Guenther, A., Vierling, L., Geron, C., and Zimmerman, P.: Biogenic volatile organic compound emissions (BVOCs) I. Identifications from three continental sites in the U.S., Chemosphere, 38, 2163-2187, doi:10.1016/S00456535(98)00425-1, 1999.

Helmig, D., Ortega, J., Guenther, A., Herrick, J. D., and Geron, C.: Sesquiterpene emissions from loblolly pine and their potential contribution to biogenic aerosol formation in the Southeastern US, Atmos. Environ., 40, 4150-4157, doi:10.1016/j.atmosenv.2006.02.035, 2006.

Herrmann, K.: The Shikimate Pathway: Early Steps in the Biosynthesis of Aromatic Compounds., Plant Cell, 7, 907-919, 1995.

Holland, M. A. and Polacco, and J. C.: PPFMs and Other Covert Contaminants: Is There More to Plant Physiology Than Just Plant?, Annu. Rev. Plant Physiol. Plant Mol. Biol., 45, 197-209, doi:10.1146/annurev.pp.45.060194.001213, 1994.

Holzinger, R., Sandoval-Soto, L., Rottenberger, S., Crutzen, P. J., and Kesselmeier, J.: Emissions of volatile organic compounds from Quercus ilex L. measured by Proton Transfer Reaction Mass Spectrometry under different environmental conditions, J. Geophys. Res.-Atmos., 105, 20573-20579, doi:10.1029/2000JD900296, 2000.

Hüve, K., Christ, M. M., Kleist, E., Uerlings, R., Niinemets, Ü., Walter, A., and Wildt, J.: Simultaneous growth and emission measurements demonstrate an interactive control of methanol re- 
lease by leaf expansion and stomata, J. Exp. Bot., 58, 1783-1793, doi:10.1093/jxb/erm038, 2007.

Isidorov, V. A., Zenkevich, I. G., and Ioffe, B. V.: Volatile organic compounds in the atmosphere of forests, Atmospheric Environ., 19, 1-8, doi:10.1016/0004-6981(85)90131-3, 1985.

Jacob, D. J., Field, B. D., Jin, E. M., Bey, I., Li, Q., Logan, J. A., Yantosca, R. M., and Singh, H. B.: Atmospheric budget of acetone, J. Geophys. Res.-Atmos., 107, ACH 5-1-ACH 5-17, doi:10.1029/2001JD000694, 2002.

Janson, R. and de Serves, C.: Acetone and monoterpene emissions from the boreal forest in northern Europe, Atmos. Environ., 35, 4629-4637, doi:10.1016/S1352-2310(01)00160-1, 2001.

Jardine, K., Harley, P., Karl, T., Guenther, A., Lerdau, M., and Mak, J. E.: Plant physiological and environmental controls over the exchange of acetaldehyde between forest canopies and the atmosphere, Biogeosciences, 5, 1559-1572, doi:10.5194/bg-5-15592008, 2008.

Jardine, K., Abrell, L., Kurc, S. A., Huxman, T., Ortega, J., and Guenther, A.: Volatile organic compound emissions from Larrea tridentata (creosotebush), Atmos. Chem. Phys., 10, 1219112206, doi:10.5194/acp-10-12191-2010, 2010.

Jardine, K. J., Monson, R. K., Abrell, L., Saleska, S. R., Arneth, A., Jardine, A., Ishida, F. Y., Serrano, A. M. Y., Artaxo, P., Karl, T., Fares, S., Goldstein, A., Loreto, F., and Huxman, T.: Within-plant isoprene oxidation confirmed by direct emissions of oxidation products methyl vinyl ketone and methacrolein, Glob. Change Biol., 18, 973-984, doi:10.1111/j.1365-2486.2011.02610.x, 2012.

Jordan, A., Haidacher, S., Hanel, G., Hartungen, E., Herbig, J., Märk, L., Schottkowsky, R., Seehauser, H., Sulzer, P., and Märk, T. D.: An online ultra-high sensitivity Proton-transfer-reaction mass-spectrometer combined with switchable reagent ion capability (PTR + SRI - MS), Int. J. Mass Spectrom., 286, 32-38, doi:10.1016/j.ijms.2009.06.006, 2009.

Kalogridis, C., Gros, V., Sarda-Esteve, R., Langford, B., Loubet, B., Bonsang, B., Bonnaire, N., Nemitz, E., Genard, A.-C., Boissard, C., Fernandez, C., Ormeño, E., Baisnée, D., Reiter, I., and Lathière, J.: Concentrations and fluxes of isoprene and oxygenated VOCs at a French Mediterranean oak forest, Atmos. Chem. Phys., 14, 10085-10102, doi:10.5194/acp-14-10085-2014, 2014.

Kanakidou, M., Seinfeld, J. H., Pandis, S. N., Barnes, I., Dentener, F. J., Facchini, M. C., Van Dingenen, R., Ervens, B., Nenes, A., Nielsen, C. J., Swietlicki, E., Putaud, J. P., Balkanski, Y., Fuzzi, S., Horth, J., Moortgat, G. K., Winterhalter, R., Myhre, C. E. L., Tsigaridis, K., Vignati, E., Stephanou, E. G., and Wilson, J.: Organic aerosol and global climate modelling: a review, Atmos. Chem. Phys., 5, 1053-1123, doi:10.5194/acp-5-1053-2005, 2005.

Karl, T., Curtis, A. J., Rosenstiel, T. N., Monson, R. K., and Fall, R.: Transient releases of acetaldehyde from tree leaves - products of a pyruvate overflow mechanism?, Plant Cell Environ., 25, 11211131, doi:10.1046/j.1365-3040.2002.00889.x, 2002a.

Karl, T. G., Spirig, C., Rinne, J., Stroud, C., Prevost, P., Greenberg, J., Fall, R., and Guenther, A.: Virtual disjunct eddy covariance measurements of organic compound fluxes from a subalpine forest using proton transfer reaction mass spectrometry, Atmos. Chem. Phys., 2, 279-291, doi:10.5194/acp-2-279-2002, 2002 b.

Karl, T., Guenther, A., Spirig, C., Hansel, A., and Fall, R.: Seasonal variation of biogenic VOC emissions above a mixed hard- wood forest in northern Michigan, Geophys. Res. Lett., 30, 2186, doi:10.1029/2003GL018432, 2003.

Karl, T., Potosnak, M., Guenther, A., Clark, D., Walker, J., Herrick, J. D., and Geron, C.: Exchange processes of volatile organic compounds above a tropical rain forest: Implications for modeling tropospheric chemistry above dense vegetation, J. Geophys. Res.-Atmos., 109, D18306, doi:10.1029/2004JD004738, 2004.

Karl, T., Harley, P., Guenther, A., Rasmussen, R., Baker, B., Jardine, K., and Nemitz, E.: The bi-directional exchange of oxygenated VOCs between a loblolly pine (Pinus taeda) plantation and the atmosphere, Atmos. Chem. Phys., 5, 3015-3031, doi:10.5194/acp5-3015-2005, 2005.

Karl, T., Harley, P., Emmons, L., Thornton, B., Guenther, A., Basu, C., Turnipseed, A., and Jardine, K.: Efficient Atmospheric Cleansing of Oxidized Organic Trace Gases by Vegetation, Science, 330, 816-819, doi:10.1126/science.1192534, 2010.

Kavouras, I. G., Mihalopoulos, N., and Stephanou, E. G.: Formation of atmospheric particles from organic acids produced by forests, Nature, 395, 683-686, doi:10.1038/27179, 1998.

Kergomard, A., Renard, M. F., Veschambre, H., Courtois, D., and Petiard, V.: Reduction of $\alpha, \beta$-unsaturated ketones by plant suspension cultures, Phytochemistry, 27, 407-409, doi:10.1016/0031-9422(88)83108-X, 1988.

Kim, S., Karl, T., Guenther, A., Tyndall, G., Orlando, J., Harley, P., Rasmussen, R., and Apel, E.: Emissions and ambient distributions of Biogenic Volatile Organic Compounds (BVOC) in a ponderosa pine ecosystem: interpretation of PTR-MS mass spectra, Atmos. Chem. Phys., 10, 1759-1771, doi:10.5194/acp-101759-2010, 2010.

Kim, S., Guenther, A., Karl, T., and Greenberg, J.: Contributions of primary and secondary biogenic VOC tototal $\mathrm{OH}$ reactivity during the CABINEX (Community Atmosphere-Biosphere INteractions Experiments)-09 field campaign, Atmos. Chem. Phys., 11, 8613-8623, doi:10.5194/acp-11-8613-2011, 2011.

Kirch, H.-H., Bartels, D., Wei, Y., Schnable, P. S., and Wood, A. J.: The ALDH gene superfamily of Arabidopsis, Trends Plant Sci., 9, 371-377, doi:10.1016/j.tplants.2004.06.004, 2004.

Kirstine, W., Galbally, I., Ye, Y., and Hooper, M.: Emissions of volatile organic compounds (primarily oxygenated species) from pasture, J. Geophys. Res.-Atmos., 103, 10605-10619, doi:10.1029/97JD03753, 1998.

Knudsen, J. T., Eriksson, R., Gershenzon, J., and Ståhl, B.: Diversity and distribution of floral scent, Bot. Rev., 72, 1-120, doi:10.1663/0006-8101(2006)72[1:DADOFS]2.0.CO;2, 2006.

Kondo, T., Hasegawa, K., Kitagawa, C., Uchida, R., and Onishi, M.: Absorption of Atmospheric Phenol by Evergreen Broad-leaved Tree Species., Chem. Lett., 11, 997-998, doi:10.1246/cl.1996.997, 1996.

Kondo, T., Hasegawa, K., Uchida, R., and Onishi, M.: Absorption of atmospheric $\mathrm{C} 2-\mathrm{C} 5$ aldehydes by various tree species and their tolerance to C2-C5 aldehydes, Sci. Total Environ., 224, 121132, doi:10.1016/S0048-9697(98)00320-9, 1998.

Kreuzwieser, J., Scheerer, U., and Rennenberg, H.: Metabolic origin of acetaldehyde emitted by poplar (Populus tremula x P. alba) trees, J. Exp. Bot., 50, 757-765, doi:10.1093/jxb/50.335.757, 1999.

Laffineur, Q., Aubinet, M., Schoon, N., Amelynck, C., Müller, J.F., Dewulf, J., Van Langenhove, H., Steppe, K., and Heinesch, B.: Abiotic and biotic control of methanol exchanges in a 
temperate mixed forest, Atmos. Chem. Phys., 12, 577-590, doi:10.5194/acp-12-577-2012, 2012.

Leone, J. A. and Seinfeld, J. H.: Updated chemical mechanism for atmospheric photooxidation of toluene, Int. J. Chem. Kinet., 16, 159-193, doi:10.1002/kin.550160207, 1984.

Loreto, F. and Fineschi, S.: Reconciling functions and evolution of isoprene emission in higher plants, New Phytol., 206, 578-582, doi:10.1111/nph.13242, 2015.

Loreto, F. and Sharkey, T. D.: A gas-exchange study of photosynthesis and isoprene emission inQuercus rubra, Planta, 182, 523-531, doi:10.1007/BF02341027, 1990.

Loreto, F., Ciccioli, P., Cecinato, A., Brancaleoni, E., Frattoni, M., Fabozzi, C., and Tricoli, D.: Evidence of the Photosynthetic Origin of Monoterpenes Emitted by Quercus ilex L. Leaves by 13C Labeling, Plant Physiol., 110, 1317-1322, 1996.

Loreto, F., Ciccioli, P., Brancaleoni, E., Cecinato, A., and Frattoni, M.: Measurement of isoprenoid content in leaves of Mediterranean Quercus spp. by a novel and sensitive method and estimation of the isoprenoid partition between liquid and gas phase inside the leaves, Plant Sci., 136, 25-30, doi:10.1016/S01689452(98)00092-2, 1998

Loreto, F., Barta, C., Brilli, F., and Nogues, I.: On the induction of volatile organic compound emissions by plants as consequence of wounding or fluctuations of light and temperature, Plant Cell Environ., 29, 1820-1828, doi:10.1111/j.13653040.2006.01561.x, 2006.

Loreto, F., Bagnoli, F., and Fineschi, S.: One species, many terpenes: matching chemical and biological diversity, Trends Plant Sci., 14, 416-420, doi:10.1016/j.tplants.2009.06.003, 2009.

Macdonald, R. C. and Fall, R.: Acetone emission from conifer buds, Phytochemistry, 34, 991-994, doi:10.1016/S00319422(00)90700-3, 1993.

MacDonald, R. C. and Kimmerer, T. W.: Metabolism of Transpired Ethanol by Eastern Cottonwood (Populus deltoides Bartr.), Plant Physiol., 102, 173-179, 1993.

McKinney, K. A., Lee, B. H., Vasta, A., Pho, T. V., and Munger, J. W.: Emissions of isoprenoids and oxygenated biogenic volatile organic compounds from a New England mixed forest, Atmos. Chem. Phys., 11, 4807-4831, doi:10.5194/acp-11-4807-2011, 2011.

Misztal, P. K., Owen, S. M., Guenther, A. B., Rasmussen, R., Geron, C., Harley, P., Phillips, G. J., Ryan, A., Edwards, D. P., Hewitt, C. N., Nemitz, E., Siong, J., Heal, M. R., and Cape, J. N.: Large estragole fluxes from oil palms in Borneo, Atmos. Chem. Phys., 10, 4343-4358, doi:10.5194/acp-10-4343-2010, 2010.

Misztal, P. K., Nemitz, E., Langford, B., Di Marco, C. F., Phillips, G. J., Hewitt, C. N., MacKenzie, A. R., Owen, S. M., Fowler, D., Heal, M. R., and Cape, J. N.: Direct ecosystem fluxes of volatile organic compounds from oil palms in South-East Asia, Atmos. Chem. Phys., 11, 8995-9017, doi:10.5194/acp-11-89952011, 2011.

Misztal, P. K., Hewitt, C. N., Wildt, J., Blande, J. D., Eller, A. S. D., Fares, S., Gentner, D. R., Gilman, J. B., Graus, M., Greenberg, J., Guenther, A. B., Hansel, A., Harley, P., Huang, M., Jardine, K., Karl, T., Kaser, L., Keutsch, F. N., Kiendler-Scharr, A., Kleist, E., Lerner, B. M., Li, T., Mak, J., Nölscher, A. C., Schnitzhofer, R., Sinha, V., Thornton, B., Warneke, C., Wegener, F., Werner, C., Williams, J., Worton, D. R., Yassaa, N., and Goldstein, A. H.:
Atmospheric benzenoid emissions from plants rival those from fossil fuels, Sci. Rep., 5, 12064, doi:10.1038/srep12064, 2015.

Moody, J. L., Munger, J. W., Goldstein, A. H., Jacob, D. J., and Wofsy, S. C.: Harvard Forest regional-scale air mass composition by Patterns in Atmospheric Transport History (PATH), J. Geophys. Res.-Atmos., 103, 13181-13194, doi:10.1029/98JD00526, 1998.

Müller, K., Haferkorn, S., Grabmer, W., Wisthaler, A., Hansel, A., Kreuzwieser, J., Cojocariu, C., Rennenberg, H., and Herrmann, H.: Biogenic carbonyl compounds within and above a coniferous forest in Germany, Atmos. Environ., 40, Supplement 1, 81-91, doi:10.1016/j.atmosenv.2005.10.070, 2006.

Munger, J. W., Wofsy, S. C., Bakwin, P. S., Fan, S.-M., Goulden, M. L., Daube, B. C., Goldstein, A. H., Moore, K. E., and Fitzjarrald, D. R.: Atmospheric deposition of reactive nitrogen oxides and ozone in a temperate deciduous forest and a subarctic woodland: 1. Measurements and mechanisms, J. Geophys. Res.Atmos., 101, 12639-12657, doi:10.1029/96JD00230, 1996.

Muramoto, S., Matsubara, Y., Mwenda, C. M., Koeduka, T., Sakami, T., Tani, A., and Matsui, K.: Glutathionylation and Reduction of Methacrolein in Tomato Plants Account for Its Absorption from the Vapor Phase1[OPEN], Plant Physiol., 169, 1744-1754, doi:10.1104/pp.15.01045, 2015.

Niinemets, Ü. and Reichstein, M.: Controls on the emission of plant volatiles through stomata: Differential sensitivity of emission rates to stomatal closure explained, J. Geophys. Res.-Atmos., 108, 4208, doi:10.1029/2002JD002620, 2003.

Oikawa, P. Y. and Lerdau, M. T.: Catabolism of volatile organic compounds influences plant survival, Trends Plant Sci., 18, 695703, doi:10.1016/j.tplants.2013.08.011, 2013.

Omasa, K., Tobe, K., Hosomi, M., and Kobayashi, M.: Absorption of Ozone and Seven Organic Pollutants by Populus nigra and Camellia sasanqua, Environ. Sci. Technol., 34, 2498-2500, doi:10.1021/es991285m, 2000.

Omasa, K., Tobe, K., and Kondo, T.: Absorption of Organic and Inorganic Air Pollutants by Plants, in: Air Pollution and Plant Biotechnology, edited by: Omasa, K., Saji, H., Youssefian, S., and Kondo, N., 155-178, Springer Japan, available at: http: //link.springer.com/chapter/10.1007/978-4-431-68388-9_8 (last access: 18 May 2016), 2002.

Owen, S. M., Harley, P., Guenther, A., and Hewitt, C. N.: Light dependency of VOC emissions from selected Mediterranean plant species, Atmos. Environ., 36, 3147-3159, doi:10.1016/S13522310(02)00235-2, 2002.

Pichersky, E., Noel, J. P., and Dudareva, N.: Biosynthesis of Plant Volatiles: Nature's Diversity and Ingenuity, Science, 311, 808811, doi:10.1126/science.1118510, 2006.

Pinho, P. G., Pio, C. A., and Jenkin, M. E.: Evaluation of isoprene degradation in the detailed tropospheric chemical mechanism, MCM v3, using environmental chamber data, Atmos. Environ., 39, 1303-1322, doi:10.1016/j.atmosenv.2004.11.014, 2005.

Pöschl, U., Williams, J., Hoor, P., Fischer, H., Crutzen, P. J., Warneke, C., Holzinger, R., Hansel, A., Jordan, A., Lindinger, W., Scheeren, H. A., Peters, W., and Lelieveld, J.: High Acetone Concentrations throughout the $0-12 \mathrm{~km}$ Altitude Range over the Tropical Rainforest in Surinam, J. Atmos. Chem., 38, 115-132, doi:10.1023/A:1006370600615, 2001. 
Rasmussen, R. A. and Khalil, M. a. K.: Atmospheric benzene and toluene, Geophys. Res. Lett., 10, 1096-1099, doi:10.1029/GL010i011p01096, 1983.

Rinne, J., Taipale, R., Markkanen, T., Ruuskanen, T. M., Hellén, H., Kajos, M. K., Vesala, T., and Kulmala, M.: Hydrocarbon fluxes above a Scots pine forest canopy: measurements and modeling, Atmos. Chem. Phys., 7, 3361-3372, doi:10.5194/acp-73361-2007, 2007.

Rivera-Rios, J. C., Nguyen, T. B., Crounse, J. D., Jud, W., St. Clair, J. M., Mikoviny, T., Gilman, J. B., Lerner, B. M., Kaiser, J. B., de Gouw, J., Wisthaler, A., Hansel, A., Wennberg, P. O., Seinfeld, J. H., and Keutsch, F. N.: Conversion of hydroperoxides to carbonyls in field and laboratory instrumentation: Observational bias in diagnosing pristine versus anthropogenically controlled atmospheric chemistry, Geophys. Res. Lett., 41, 2014GL061919, doi:10.1002/2014GL061919, 2014.

Rottenberger, S., Kuhn, U., Wolf, A., Schebeske, G., Oliva, S. T., Tavares, T. M., and Kesselmeier, J.: Exchange of Short-Chain Aldehydes Between Amazonian Vegetation and the Atmosphere, Ecol. Appl., 14, 247-262, doi:10.1890/01-6027, 2004.

Schade, G. W. and Goldstein, A. H.: Fluxes of oxygenated volatile organic compounds from a ponderosa pine plantation, J. Geophys. Res.-Atmos., 106, 3111-3123, doi:10.1029/2000JD900592, 2001.

Schade, G. W. and Goldstein, A. H.: Seasonal measurements of acetone and methanol: Abundances and implications for atmospheric budgets, Global Biogeochem. Cy., 20, GB1011, doi:10.1029/2005GB002566, 2006.

Schade, G. W., Solomon, S. J., Dellwik, E., Pilegaard, K., and Ladstätter-Weissenmayer, A.: Methanol and other VOC fluxes from a Danish beech forest during late springtime, Biogeochemistry, 106, 337-355, doi:10.1007/s10533-010-9515-5, 2011.

Schallhart, S., Rantala, P., Nemitz, E., Taipale, D., Tillmann, R., Mentel, T. F., Loubet, B., Gerosa, G., Finco, A., Rinne, J., and Ruuskanen, T. M.: Characterization of total ecosystem-scale biogenic VOC exchange at a Mediterranean oak-hornbeam forest, Atmos. Chem. Phys., 16, 7171-7194, doi:10.5194/acp-16-71712016, 2016.

Schneider, C. A., Rasband, W. S., and Eliceiri, K. W.: NIH Image to ImageJ: 25 years of image analysis, Nat. Methods, 9, 671-675, doi:10.1038/nmeth.2089, 2012.

Schürmann, W., Ziegler, H., Kotzias, D., Schönwitz, R., and Steinbrecher, R.: Emission of biosynthesized monoterpenes from needles of Norway Spruce, Naturwissenschaften, 80, 276-278, doi:10.1007/BF01135913, 1993.

Seco, R., Karl, T., Guenther, A., Hosman, K. P., Pallardy, S. G., Gu, L., Geron, C., Harley, P., and Kim, S.: Ecosystem-scale volatile organic compound fluxes during an extreme drought in a broadleaf temperate forest of the Missouri Ozarks (central USA), Glob. Change Biol., 21, 3657-3674, doi:10.1111/gcb.12980, 2015

Sharkey, T. D., Singsaas, E. L., Vanderveer, P. J., and Geron, C.: Field measurements of isoprene emission from trees in response to temperature and light, Tree Physiol., 16, 649-654, 1996.

Shimoda, K., Kubota, N., Hamada, H., Yamane, S., and Hirata, T.: Asymmetric Transformation of Enones with Synechococcus sp. PCC 7942, Bull. Chem. Soc. Jpn., 77, 2269-2272, doi:10.1246/bcsj.77.2269, 2004.
Spirig, C., Neftel, A., Ammann, C., Dommen, J., Grabmer, W., Thielmann, A., Schaub, A., Beauchamp, J., Wisthaler, A., and Hansel, A.: Eddy covariance flux measurements of biogenic VOCs during ECHO 2003 using proton transfer reaction mass spectrometry, Atmos. Chem. Phys., 5, 465-481, doi:10.5194/acp-5-465-2005, 2005.

Steinbrecher, R., Smiatek, G., Köble, R., Seufert, G., Theloke, J., Hauff, K., Ciccioli, P., Vautard, R., and Curci, G.: Intra- and inter-annual variability of VOC emissions from natural and seminatural vegetation in Europe and neighbouring countries, Atmos. Environ., 43, 1380-1391, doi:10.1016/j.atmosenv.2008.09.072, 2009.

Tang, Y.-X. and Suga, T.: The International Journal of Plant BiochemistryBiotransformation of $\alpha$ - and $\beta$-ionones by immobilized cells of Nicotiana tabacum, Phytochemistry, 37, 737-740, doi:10.1016/S0031-9422(00)90349-2, 1994.

Tani, A. and Hewitt, C. N.: Uptake of Aldehydes and Ketones at Typical Indoor Concentrations by Houseplants, Environ. Sci. Technol., 43, 8338-8343, doi:10.1021/es9020316, 2009.

Titzmann, T., Graus, M., Müller, M., Hansel, A., and Ostermann, A.: Improved peak analysis of signals based on counting systems: Illustrated for proton-transfer-reaction time-offlight mass spectrometry, Int. J. Mass Spectrom., 295, 72-77, doi:10.1016/j.ijms.2010.07.009, 2010.

Ugrekhelidze, D., Korte, F., and Kvesitadze, G.: Uptake and Transformation of Benzene and Toluene by Plant Leaves, Ecotoxicol. Environ. Saf., 37, 24-29, doi:10.1006/eesa.1996.1512, 1997.

Ugrekhelidze, D. S.: Metabolism of Exogenous Alkanes and Aromatic Hydrocarbons in Plants, Metsniereba, Tbilisi, 1976.

Urbanski, S., Barford, C., Wofsy, S., Kucharik, C., Pyle, E., Budney, J., McKain, K., Fitzjarrald, D., Czikowsky, M., and Munger, J. W.: Factors controlling $\mathrm{CO}_{2}$ exchange on timescales from hourly to decadal at harvard forest, J. Geophys. Res.-Biogeo., 112, G02020, doi:10.1029/2006jg000293, 2007.

Velikova, V., Fares, S., and Loreto, F.: Isoprene and nitric oxide reduce damages in leaves exposed to oxidative stress, Plant Cell Environ., 31, 1882-1894, doi:10.1111/j.13653040.2008.01893.x, 2008.

Vickers, C. E., Possell, M., Cojocariu, C. I., Velikova, V. B., Laothawornkitkul, J., Ryan, A., Mullineaux, P. M., and Nicholas Hewitt, C.: Isoprene synthesis protects transgenic tobacco plants from oxidative stress, Plant Cell Environ., 32, 520-531, doi:10.1111/j.1365-3040.2009.01946.x, 2009.

Vollenweider, S., Weber, H., Stolz, S., Chételat, A., and Farmer, E. E.: Fatty acid ketodienes and fatty acid ketotrienes: Michael addition acceptors that accumulate in wounded and diseased Arabidopsis leaves, Plant J. Cell Mol. Biol., 24, 467-476, 2000.

Wanner, P. and Tressl, R.: Purification and characterization of two enone reductases from Saccharomyces cerevisiae, Eur. J. Biochem., 255, 271-278, doi:10.1046/j.14321327.1998.2550271.x, 1998.

White, M. L., Russo, R. S., Zhou, Y., Ambrose, J. L., Haase, K., Frinak, E. K., Varner, R. K., Wingenter, O. W., Mao, H., Talbot, R., and Sive, B. C.: Are biogenic emissions a significant source of summertime atmospheric toluene in the rural Northeastern United States?, Atmos. Chem. Phys., 9, 81-92, doi:10.5194/acp9-81-2009, 2009.

Winters, A. J., Adams, M. A., Bleby, T. M., Rennenberg, H., Steigner, D., Steinbrecher, R., and Kreuzwieser, J.: Emissions of 
isoprene, monoterpene and short-chained carbonyl compounds from Eucalyptus spp. in southern Australia, Atmos. Environ., 43, 3035-3043, doi:10.1016/j.atmosenv.2009.03.026, 2009.

Wohlfahrt, G., Brilli, F., Hörtnagl, L., Xu, X., Bingemer, H., Hansel, A., and Loreto, F.: Carbonyl sulfide (COS) as a tracer for canopy photosynthesis, transpiration and stomatal conductance: potential and limitations $\dagger$, Plant Cell Environ., 35, 657-667, doi:10.1111/j.1365-3040.2011.02451.x, 2012.
Yáñez-Serrano, A. M., Nölscher, A. C., Bourtsoukidis, E., Derstroff, B., Zannoni, N., Gros, V., Lanza, M., Brito, J., Noe, S. M., House, E., Hewitt, C. N., Langford, B., Nemitz, E., Behrendt, T., Williams, J., Artaxo, P., Andreae, M. O., and Kesselmeier, J.: Atmospheric mixing ratios of methyl ethyl ketone (2butanone) in tropical, boreal, temperate and marine environments, Atmos. Chem. Phys., 16, 10965-10984, doi:10.5194/acp16-10965-2016, 2016. 